STUDIA HISTORICA GEDANENSIA

TOM XII (2021)

\author{
Zbigniew Landowski \\ (Uniwersytet Gdański) \\ https://orcid.org/0000-0002-2747-2898
}

\title{
Reakcje społeczne na pierwszą pandemię cholery w carskiej Rosji na podstawie przeglądu prasy i dokumentów z epoki (XIX w.)
}

Słowa kluczowe: epidemia, cholera, umieralność, bunty choleryczne, cerkiew, Filaret (Drozdow), fumigacje, wózki choleryczne, osadnicy wojskowi

Keywords: epidemic, cholera, mortality, Cholera Riots, orthodox church, Filaret (Drozdov), fumigations, cholera carts, military settlers

Pracę oparto na opracowaniach i źródłach drukowanych - prasie i dokumentach z epoki (wspomnienia, raporty), niejednokrotnie redagowanych/publikowanych dopiero w XX w. Jej nowizna naukowa opiera się na syntetycznym charakterze publikacji, wykorzystaniu materiałów nieobecnych w polskiej literaturze przedmiotu i próbie scharakteryzowania reakcji społecznych na zjawiska związane zarówno z samą chorobą, jak i ówczesnymi metodami zwalczania jej. Ramy chronologiczne badania obejmują okres tzw. drugiej epidemii cholery w Rosji (według niektórych badaczy była to jedynie późna faza poprzedniej, obie były częściami pierwszej pandemii tej choroby) ${ }^{1}$, a terytorialnie badanie dotyczy głównie guberni europejskich, koncentrując się na kilku wybranych ośrodkach.

W pracy wypunktowano najważniejsze typy reakcji społeczeństwa na oba wspomniane procesy, ukazując je w kontekście ówczesnego stanu świadomości społecznej tego zagrożenia (identyfikacji choroby, poglądów na metody jej zapobiegania, ograniczania jej zasięgu i leczenia), oraz deskrypcji zarysu działań władz podjętych do walki z epidemią. Tok ich postępowania - według

\footnotetext{
1 Ксения С. Барабанова, Эпидемия холеры в Санкт-Петербурге в 1831 г.: власть и горожане в условиях чрезвычайной ситуации, ВАК РФ 07.00.02, 2017, za: disserCat Электронная библиотека диссертаций, https://www.dissercat.com/content/epidemiya-kholeryv-sankt-peterburge-v-1831-g-vlast-i-gorozhane-v-usloviyakh-chrezvychainoi-, dostęp: 29 XI 2021 r.
} 
założonej hipotezy roboczej - był równocześnie przyczyną i rezultatem takiego, a nie innego rezonansu społecznego na pandemię w carskiej Rosji lat czterdziestych XIX w. Ponieważ ówczesne przesilenia społeczne, tj. bunty choleryczne w Rosji, spacyfikowano, nie poświęcono tu więcej miejsca analizie dróg „przezwyciężania kryzysu”.

We wcześniejszych badaniach społecznego oddźwięku wspomnianych zjawisk w ZSRR (lata dwudzieste-trzydzieste XX w.) postrzegano je wyłącznie z perspektywy walki klasowej, jako „rewolucyjną odpowiedź” proletariatu na „kapitalistyczny” system władzy w ówczesnej Rosji². Dziś perspektywa naukowa uległa zmianie i rezultaty niniejszego badania mają - w założeniu - wesprzeć tendencję obiektywizacji badań historycznych procesów, które dokonywały się w ówczesnej Rosji.

Literatura dotycząca epidemii cholery w Rosji w latach trzydziestych XIX w. jest dosyć rozbudowana, źródła jej dotyczące zachowane są w wielu archiwach, między innymi w Archiwum Państwowym Federacji Rosyjskiej (znajdują się tam aż 62 obszerne zasoby dotyczące epidemii cholery w Rosji w pierwszej połowie XIX w. $)^{3}$, ukazało się też kilka opracowań mniej lub bardziej sumarycznych (m.in. sporządzonych dla konkretnych regionów państwa). Inaczej wygląda sytuacja dotycząca tematyki reakcji ludowych, a szczególnie tzw. buntów cholerycznych. Zdaniem wielu współczesnych badaczy zostały one ( $\mathrm{tj}$. dokumenty archiwalne i wspomnienia oraz ich opracowania) zmanipulowane przez działalność carskiej cenzury państwowej (instytucjonalnej i świadomościowej). Z kolei późniejsze prace (z okresu ZSRR) dokonały odmiennej dezinformacji, przedstawiając te same fakty jako przejawy innych zjawisk społeczno-historycznych. W pierwszym przypadku władzom carskim zależało na utrwaleniu przekonania o charakterze buntów jako przejawów ignorancji czerni, w drugim - jako oznak świadomej walki politycznej, nazywanej klasową. Niezależnie od tego jedne i drugie badania ustaliły - z grubsza - przebieg wydarzeń w ważniejszych ogniskach (tj. miastach) buntu osadników wojskowych czy w Tambowie, ale nadal niewiele wiadomo o początku rozruchów w Petersburgu, ich prowodyrach i późniejszym zakresie represji wobec uczestników zamieszek (ich formy, zakres i liczebność ofiar).

Ważniejsze pozycje w literaturze to - oprócz prac ogólnych, na przykład K.G. Wasiliewa i L.J. Segala ${ }^{4}$ czy Ch.E. Henze'a ${ }^{5}-$ między innymi publikacja

2 Олег В. Матвеев, „Восстание 1831 года в Новгородских военных поселениях”, Новгородский архивньй вестник 3 (2002): 58.

3 Максим В. Трушин, „Борьба с холерой в Казанской губернии (1-я половина середина XIX века)”, История и педагогика естествознания 1 (2020): 43.

4 Константин Г. Васильев, Александр Е. Сегал, История эпидемий в России (материаль и очерки), ред. Анатолий И. Метелкина (Москва: Государственное издательство медицинской литературы, 1960), 214-344.

Charlotte E. Henze, Disease, Health Care and Government in Late Imperial Russia. Life and death on the Volga 1823-1914 (New York: Routledge, 2011). 
zwarta D.N. Żbankowa ${ }^{6}$ (il. 1), S.J. Hessena ${ }^{7}$ i P.P. Jewstafiewa ${ }^{8}$ (il. 2) czy artykuły: A.F. Uszakowa ${ }^{9}$, I.I. Dubasowa ${ }^{10}$, A.G. Sliozinskiego ${ }^{11}$ i kilka współczesnych prac ${ }^{12}$. Opublikowano także kilka tytułów memuarystycznych, na przykład zbiór Bunt wojennych posieljan $w 1831$ godu: rasskazy ochewidcew ${ }^{13}$, listy Kristina do hrabiny S.A. Bobrinskiej ${ }^{14}$, dzienniki N.P. Sinelnikowa ${ }^{15}$ czy A.W. Nikitenki ${ }^{16}$.

W zakresie źródeł prasowych korzystałem głównie z zasobów archiwalnych dziennika Спверная Пчела (Рótnocna Pszczoła), wydawanego w Petersburgu w latach 1825-1864 (1825-1861 i 1863-1864), gazety będącej niejawnym organem III Oddziału (ochrany; il. 3).

Historia świata bogata jest w katastrofy - pandemie chorób, które uśmierciły miliony ludzi. W XIX w. naliczono kilka pandemii cholery, według tradycyjnej chronologii było ich pięć w latach: 1817-1823, 1826-1837, 1846-1862, 1864-1872, 1883-1896 ${ }^{17}$, według dzisiejszych kryteriów było ich mniej. Dotyczyło to też carskiej Rosji, gdzie w tym okresie kilkukrotnie wybuchała cholera. Zdaniem I. Janickiej najtragiczniej zaznaczył się 1848 r., gdy tylko w guberni mohylewskiej w ciągu sześciu miesięcy zachorowało ponad 48 tys. ludzi $\left(31,4 \%\right.$ z nich zmarło ${ }^{18}$. Już wcześniejsza

6 Холерные эпидемии в Смоленской губернии 1831-1872 г2., ред. Дмитрий Н. Жбанковъ (Смоленскъ: Типографія Ф.В. Зельдович, 1893).

7 Сергей Я. Гессен, Холерные бунты (1830-1832) (Москва: Издательство Всесоюзного общества политкаторжан и ссыльнопоселенцев, 1932).

8 Павел П. Евстафьев, Восстание военньх поселян Новгородской губернии в 1831 г. (Москва: Издательство Всесоюзного общества политкаторжан и ссыльнопоселенцев, 1935).

9 Федор А. Ушаков, „Холерный бунт в Старой Руссе. 1831. (Рассказ очевидца)”, Русская старина 1, т. 9 (1874).

10 Иван И. Дубасов, „Тамбовская холерная смута в 1830-1831 гг.", Исторический вестник 9 (1887).

11 Александр Г. Слезскинскій, „Бунт военных поселян в холеру 1831 года”, Исторический вестник 8, т. 53 (1893): 390-402.

12 Zob. Татьяна Г. Фруменкова, „Восстание новгородских военных поселян в 1831 г. и православное духовенство”, w Новгородский государственный университет. Прошлое Новгорода и Новгородской земли. Великий Новгород (Н. Новгород 1993); Олег В. Матвеев, „Восстание 1831 г. в Новгородских военных поселениях”, Новгородский архивньй вестник 3 (2002); Валерий В. Канищев, Юрий В. Мещеряков, Евгений Владиславович Яковлев, „Источники изучения поведения населения и деятельности властей Тамбовской губернии в условиях холерных эпидемий XIX в.", Вестник Тамбовского Университета. Гуманитарные Науки 1 (2006): 15-27.

13 Бунт военных поселян в 1831 году: Рассказы и воспоминания очевидцев (СанктПетербург: печ. В.И. Головина, 1870).

14 „Холера в Москве (1830): Из писем Кристина к графине С.А. Бобринской”, Русский архив 5, т. 3 (1884).

15 „Записки Н.П. Синельникова”, Исторический вестник Январь-февраль 59 (1895).

16 Александр В. Никитенко, Дневник. Т. 1 (1826-1857) (Москва: Захаров, 2005).

17 Васильев, Сегал, История эпидемий в России, 247.

18 Iwona Janicka, „Uwarunkowania i przebieg epidemii cholery w guberni mohylewskiej w 1848 roku", Przeszłość Demograficzna Polski 40 (2018): 215-243. 


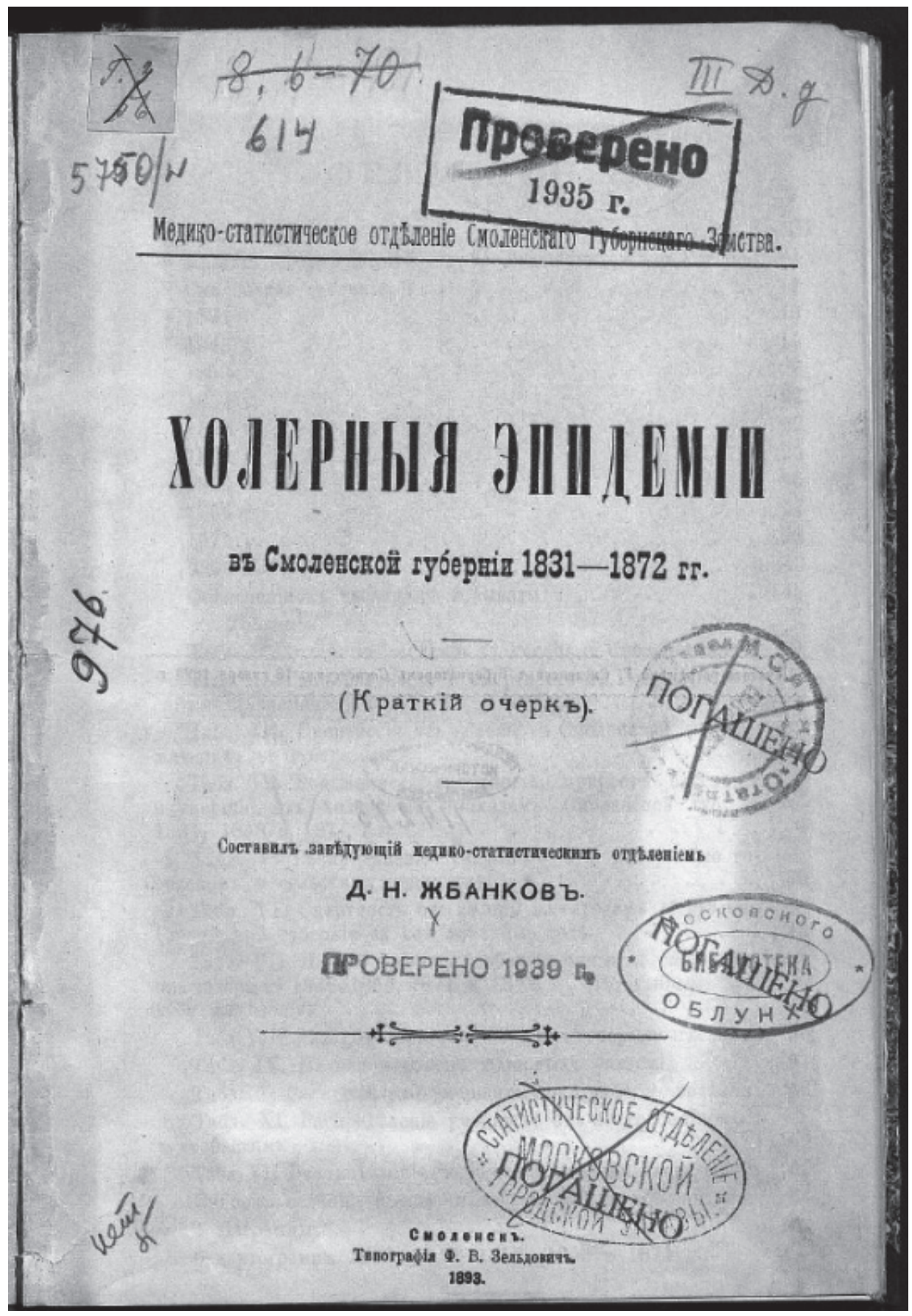

Il 1. Okładka książki Холерные эпидемии в Смоленской губернии 1831-1872 гг., печ. Д.Н. Жбанков (Смоленск 1893)

Fot. Zbigniew Landowski 


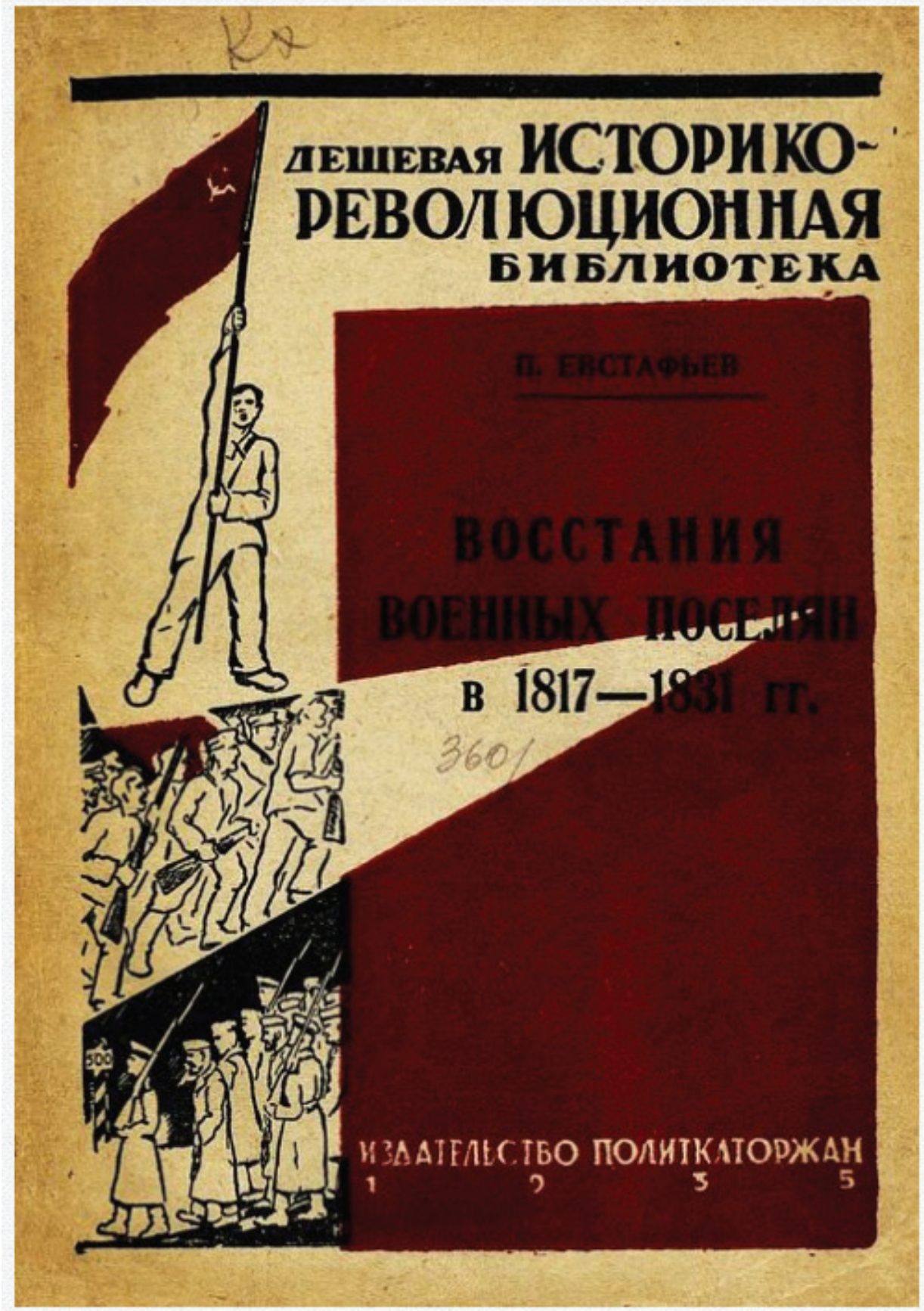

Il. 2. Okładka książki П.П. Евстафьев, Восстание военных поселян Новгородской губернии в 1831 г. (Москва 1934)

Fot. Zbigniew Landowski 


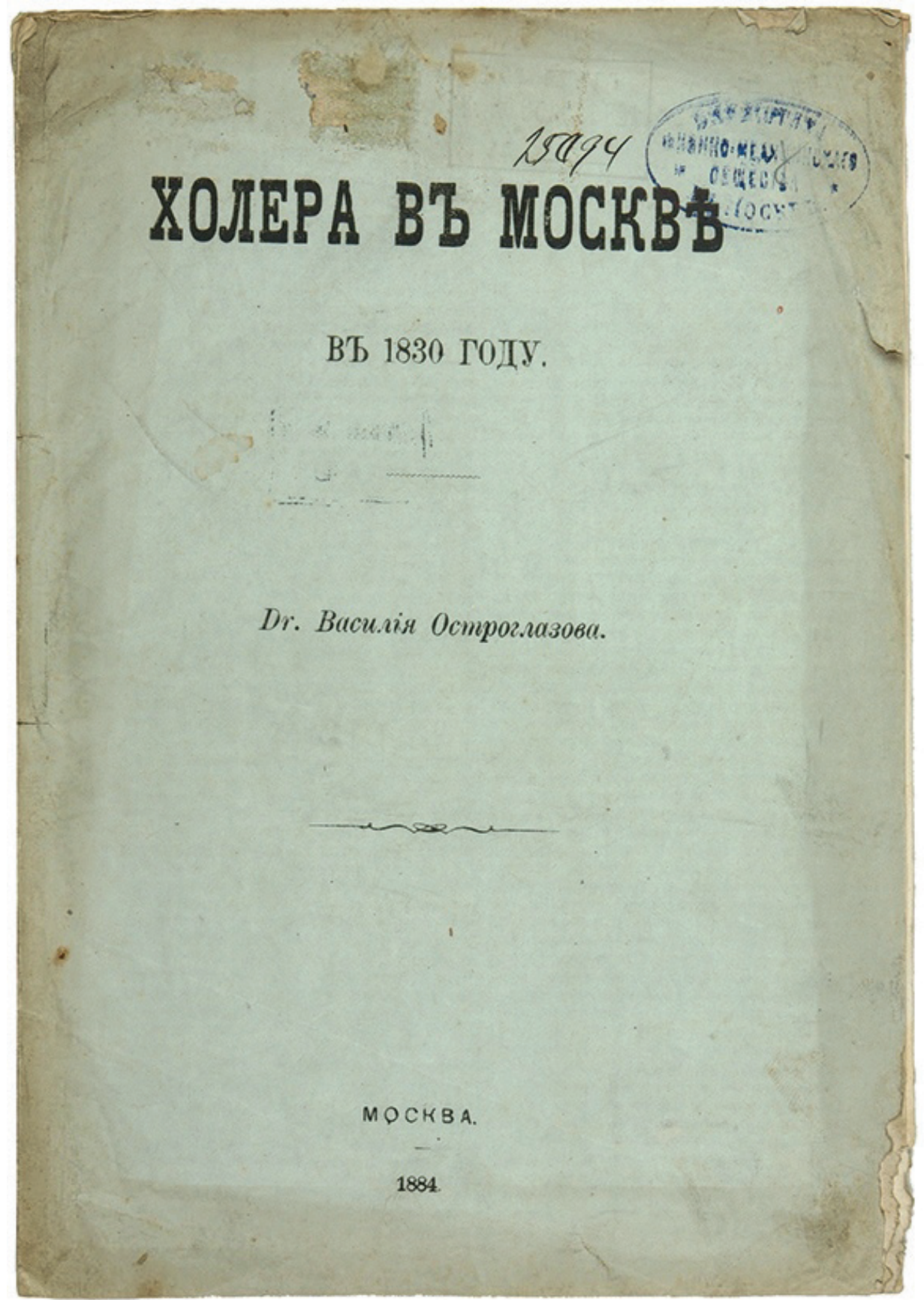

Il. 3. Okładka książki B.M. Остроглазов, Холера в Москве в 1830 году (Москва 1884) Fot. Zbigniew Landowski 
historia Rosji znała epidemie - dżumy, malarii, cholery, tyfusu, jednak najwięcej świadectw dotyczy bliskiej przeszłości, tj. XIX i XX w. Kiedy tron w 1826 r. objął Mikołaj I Romanow ${ }^{19}$, odziedziczył on administrację państwa po swoim poprzedniku i modernizował ją powoli, stąd za jego czasów liczba urzędników zatrudnionych w Departamencie Medycznym Sztabu Generalnego Ministerstwa Spraw Wojskowych w stosunku do liczby pozostałych biuralistów tegoż Ministerstwa była niewielka: kadry Departamentu Medycznego liczyły 28 osób, w porównaniu do 633 urzędników zatrudnionych we wszystkich innych centralnych urzędach tego Ministerstwa. Na przykład w innych Departamentach zatrudniano wówczas: w Audytorskim 37 osób, w Kancelarii Ogólnej - 65, a w Inżynieryjnym - 65 itd. ${ }^{20}$ Tymczasem właśnie wtedy, kiedy państwowy aparat kierowania służbą zdrowia był tak nieliczny, rozpoczęła się w imperium kolejna epidemie cholery.

W tym czasie cholera była chorobą niezbadaną (R. Koch zidentyfikował bakterię cholery w 1883 r.), „w Moskwie zdecydowanie większa część medyków była zdania, że choroba nie jest zaraźliwa, [...] lekarze byli przekonani, że choroba przybywa wraz z łodziami, które płynęły Wołgą na północ, [...] i pierwszymi jej ofiarami zawsze byli marynarze, dopiero potem choroba pojawiała się wśród mieszczan"21. Dopiero po jakimś czasie zestawiono i opisano jej objawy: „Obfita wodnista biegunka o «rybim zapachu» lub pojawienie się stolców o konsystencji «wody ryżowej»; wymioty; tachykardia (przyspieszony puls); suchość skóry; suchość błon śluzowych i jamy ustnej; nadmierne pragnienie; niskie ciśnienie krwi; skurcze mięśni; niepokój lub drażliwość; letarg/nietypowa senność lub zmęczenie; szkliste oczy, odwodnienie/brak łez; ograniczone wydalanie moczu"22. W dodatku infekcja miała często gwałtowny przebieg. Brytyjski lekarz tak opisał przypadek cholery (1831 r.) w Wielkiej Brytanii: w sobotę pacjent dostał gorączki, skurczów żołądka i niekontrolowanej wybuchowej biegunki, a następnego ranka był: „ewidentnie umierający; jego puls był prawie nieodczuwalny, kończyny zimne, skóra sucha, oczy zapadnięte, usta sine, rysy skurczone, mówił szeptem, miał gwałtowne wymioty i biegunkę, skurcze łydek i nóg, był całkowicie osłabiony"23.

Cholera to choroba społeczna - natychmiast doświadcza jej zakażony wraz z całym swoim szerokim otoczeniem, środowiskiem, w dodatku „nie tylko w czasie epidemii, ale przed nią i po niej”24.

19 Николай I Павлович (1796-1855).

20 Столютіе военнаго министерства. 1802-1902. Историческій очеркъ развитія военнаго управленія въ Россіи, т. VIII, часть 2 (Санкт-Петербургъ: Типографія П.Ф. Пантелеева, 1902), 3.

${ }^{21}$ Amanda J. Thomas, Cholera. The Victorian Plague. Pen and Sword Books (Barnsley: Pen and Sword Books, 2015), 32. Wszystkie przekłady w tekście autora, chyba, że oznaczono inaczej.

${ }^{22}$ Susan L. Kotar, Joan E. Gessler, Cholera A Worldwide History (Jefferson: McFarland \& Company, Inc., 2014), 7.

23 Robert J. Morris, Cholera 1832. The Social Response to An Epidemic (London: Croom Helm, 1976), 11.

24 Christopher Hamlin, Cholera: The Biography (Oxford: Oxford University Press, 2009), 2-3. 


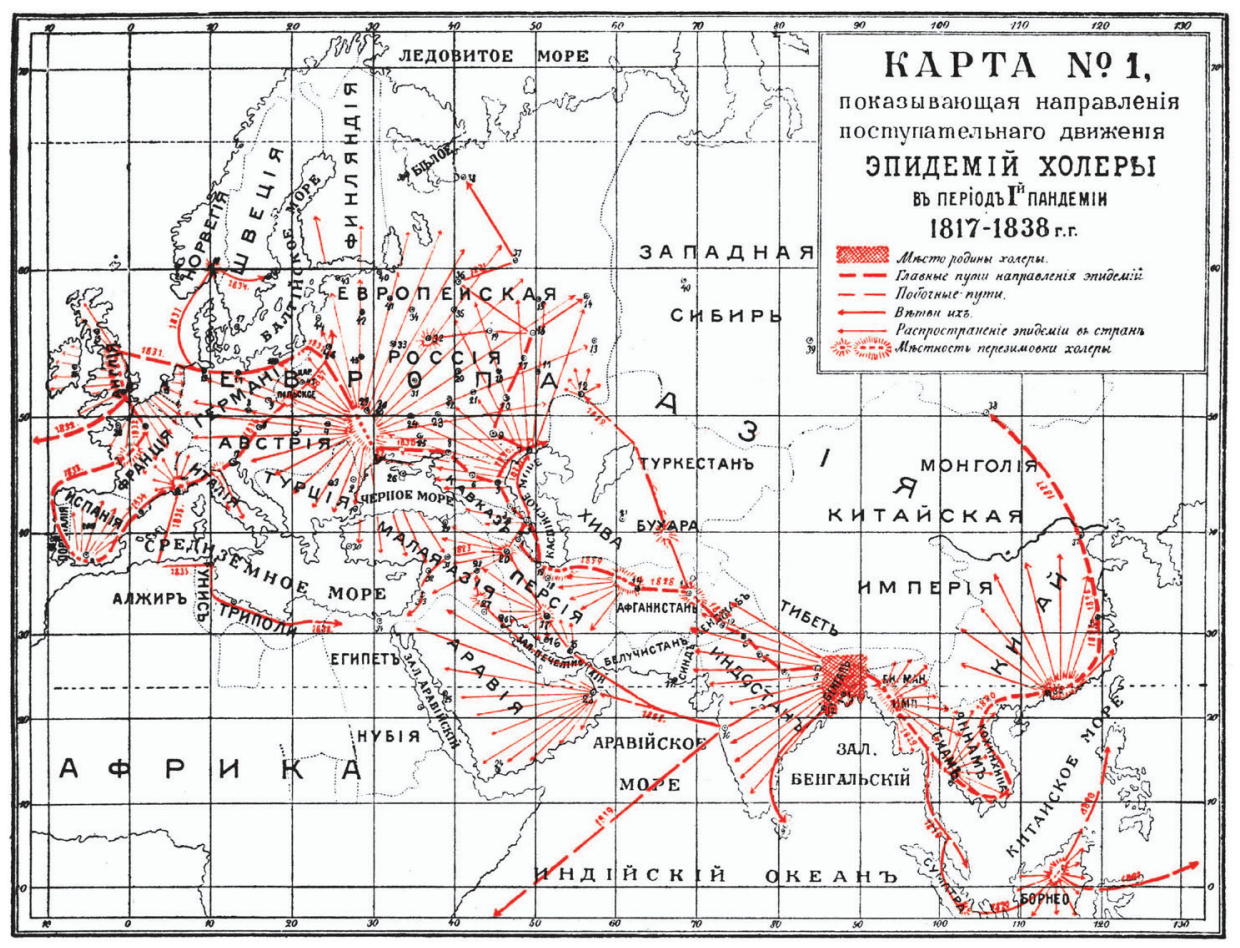

Mapa 1. Kierunki rozprzestrzeniania się cholery w latach pierwszej pandemii

Źródło: Столютіе военнаго министерства. 1802-1902. Исторический очерк развития и деятельности военно-медицинского ведомства в иарствование Императора Николая I, т. 8, кн. 2 (Санкт-Петербургъ 1908), https://runivers.ru/upload/iblock/aab/591825.png, dostęp: 28 XI $2021 \mathrm{r}$.

Pierwsza pandemia cholery trwała od 1817 do 1824 r., kiedy z Indii trafiła między innymi do Rosji ${ }^{25}$, i zbiegła się w czasie z początkiem nowej ery w historii świata: ekonomicznej transformacji systemu światowego ${ }^{26}$. Druga rozpoczęła się w 1826 i trwała do 1837 r., a w Rosji pierwsze raporty o cholerze Rada Medyczna w Petersburgu otrzymała z Orenburga dopiero 8 października 1829 r. od lekarza sztabowego Smirnowa. Historycznie było to ważkie wydarzenie, gdyż „był to pierwszy przypadek przeniknięcia i rozprzestrzenienia się cholery na terytorium Europy" ${ }^{27}$. Zachowały się dokumenty historyczne świadczące o tym horrendum w latach 1829-1830: Zbiór aktów i obserwacji dotyczących cholery,

\footnotetext{
25 Janicka, Uwarunkowania, 216.

26 Myron Echenberg, Africa in the Time of Cholera. A History of Pandemics from 1817 to the Present (New York: Cambridge University Press, 2011), 15.

27 Ирина Э. Ляшенко, Валентина И. Желтова, Михаил В. Скачков, „Из истории борьбы с холерой в Оренбургском крае (к 175-летию первой эпидемии холеры в Оренбурге)”, Эпидемиология и вакиинопрофилактика 1 (2005): 59.
} 
która rozprzestrzeniła się pod koniec $1829 \mathrm{r}$. i trwała do początku $1830 \mathrm{r}$. w guberni orenburskiej. Prześledzono w nich drogi rozprzestrzeniania się choroby: przyniosły ją karawany handlowe z Buchary, Chiwy i Turkiestanu ${ }^{28}$. W guberni orenburskiej cholera trwała do stycznia 1830 r., potem pojawiła się w Astrachaniu. Tam, pięćdziesiąt kilometrów od miasta, znaleziono ośmiu chorych na cholerę członków załogi brygu „Baku”, który przybył z południowej części Morza Kaspijskiego (z Lenkoranu, obecnie w Azerbejdżanie). W mieście od 20 czerwca do 15 sierpnia zachorowało 3633 osób, z których zmarło $2935^{29}$. „Niemalże nie było domu, gdzie nie byłoby chorego albo zmarłego na cholerę, a prawie wszyscy zdrowi ludzie byli osłabieni, przemęczeni, bladzi na twarzy, czuli suchość w ustach, pragnienie i częste bóle w jamie brzusznej, niektórzy mieli nawet drgawki nóg"30. Z Astrachania infekcja rozprzestrzeniła się Wołgą na północ kraju: do Saratowa, Samary, Kazania. 4 września 1830 r. cesarz wydał dekret wzywający Senat do podjęcia konkretnych środków i przedsięwzięć w celu zwalczania epidemii w niektórych prowincjach ${ }^{31}$. 17 września tego roku cholerę stwierdzono już w Moskwie ${ }^{32}$.

\section{Reakcje władz}

Mimo braku medycznej wiedzy na temat samej choroby kroki podjęte przez władze były nadzwyczajne i wzorowane na doświadczeniach z poprzedniej wielkiej epidemii - dżumy. W 1830 r. w starej stolicy zwołano Radę Medyczną, w której po raz pierwszy na równych prawach wzięli udział główni lekarze wszystkich moskiewskich szpitali, profesorowie Akademii Medycznej i najlepsi moskiewscy lekarze ${ }^{33}$. W Petersburgu pierwszy pacjent, u którego rozpoznano chorobę (pomocnik malarza) zmarł 14 czerwca, a już 16 czerwca zebrał się tam komitet powołany w celu podjęcia kroków przeciw rozprzestrzenieniu się jej ${ }^{34}$. W jego skład, oprócz wojskowego gubernatora generalnego stolicy Piotra K. Essena, weszli adiutanci wyższych dowódców wojskowych (czyli przedstawiciele władzy wykonawczej w stolicy), lekarze i szef III Sekcji Kancelarii Jego Cesarskiej Mości ${ }^{35}$. Jeden z reprezentowanych tu medyków później

28 Владислав С. Ганин, „Исторический взгляд на эволюцию холерной инфекции”, Клио 2 (2010): 61.

29 Ibidem.

30 Николай К. Щепотьев, Чумныя и холерныя эпидеміи въ Астраханской губерніи (Казань: Типографія Императорскаго Университета, 1884), 90.

31 Трушин, Борьба с холерой, 39.

32 Ганин, Исторический взгляд, 61.

33 Светлана В. Райкова, „Из истории борьбы с холерными эпидемиями в России”, Актуальные проблемы гуманитарных и естественных наук 7, часть 1 (2013): 114.

34 Дмитрий Шерих, Агонизирующая столииа. Как Петербург противостоял семи страшнейшим эпидемиям холеры (Санкт-Петербург: ЗАО „Издательство Центрполиграф”, 2014), 11.

35 Ibidem. 
popełnił dwie broszury o cholerze ${ }^{36} .16$ września 1830 r. minister Arsenij A. Zakriewskij (Арсений Андреевич Закревский) ustanowił godzinę policyjną, zakazał mieszkańcom domów, w których przebywali chorzy, wychodzenia na ulicę bez specjalnych pozwoleń. Osoby, które znalazły się w odosobnieniu w domu i nie posiadały zapasów, miały dostawać jedzenie na kredyt, zwracany po zniesieniu kwarantanny. Dorosłym asygnowano przydział racji żywnościowej szeregowca, dzieciom - jej połowę, dodatkowo dopłacano wszystkim po 5 kopiejek dziennie na osobę. Ponadto przyznawano reglamentowany kontyngent opału - jeden sążeń drewna ${ }^{37}$. Świadek wydarzeń tak opisał ówczesne życie stolicy: „W końcu cholera wraz ze wszystkimi swoimi okropieństwami dotarła do Petersburga. Wszędzie podejmowane są ścisłe środki ostrożności. Miasto jest w udręce. Prawie wszystkie komunikacje zostały przerwane. Ludzie opuszczają swoje domy tylko wtedy, gdy jest to absolutnie konieczne lub z powodu wykonywanej pracy" 38 .

Gdy cholera zagroziła nadejściem do Kazania, gubernator wydał 19 września 1830 r. rozporządzenie nr 4184, w którym nakazywał (do czasu ustania choroby) zamknięcie w mieście i guberni publicznych placówek szkolnych, urzędów gubernialnych: biura gubernatora, urzędów skarbowych, sądów, instytucji społecznych i szlacheckich, magistratów ${ }^{39}$.

W innych miastach zamknięto przybytki publiczne (traktiernie, teatry), zakazano bicia w dzwony podczas pogrzebów, zamknięto też cerkwie. Ciała zmarłych wożono na specjalnych wozach na oddzielny cmentarz, gdzie grzebano je zbiorowo, w wapnie. Na placach miejskich przez całą dobę płonęły smolne ogniska, by oczyścić morowe powietrze, ludzie chodzili po ulicach w nasmołowanych maskach, trzymając w ręku smolne pochodnie. Prywatni lekarze zaczęli się ukrywać i odmawiać leczenia chorych, dlatego żandarmski naczelnik miasta Wiktor A. Szompuliow (Виктор Антонович Шомпулев) wydał polecenie zobowiązujące ich do udzielania chorym pomocy. Ponieważ medycy nadal jej odmawiali, policja wyłamywała drzwi do ich domów i siłą odprowadzała, pod konwojem żandarmów, do chorych. W.A. Szompuliow całymi dniami i nocami objeżdżał konno miasto, cmentarze i szpitale, kontrolując działalność wszystkich instytucji i ich personelu. Za karygodne błędy w sztuce lekarskiej jednego z kierowników szpitali aresztowano i pod konwojem odwieziono do więzienia ${ }^{40}$.

36 Яков В. Виллие, Описание индийской холеры для врачей армии (Санкт-Петербургъ: b.w., 1830); Отчеты о средствах, употребленных против холеры в военных госпиталях в С.-Петербурге с практическими замечаниями о свойствах сей болезни (Санкт-Петербургъ: Типографія Иверсена, 1831).

${ }_{37}$ Трушин, Борьба с холерой, 39-40.

38 Александр В. Никитенко, Записки и дневник (Москва 2005), 58.

39 Димитрий Д. Ахшарумов, „Холера въ Малороссіи въ 1830-1831 гг.”, Русская старина июль 47 (августъ и сентябрь 1885): 212.

40 „Из дневника жандарма 30.х годов”, Русская старина 5 (1897): 261-269, za: Виктор А. Шомпулев, Записки старого помещика (Москва: Новое литературное обозрение, 2012), 31. 
W całym państwie rozporządzeniem Ministra Spraw Wewnętrznych ustanowiono w aptekach stałe ceny niektórych leków (najczęściej stosowanych do dezynfekcji): „wapna chlorowanego na 1,6 rubla za funt, sody chlorowanej na 8 rubli za funt oraz sody chlorowanej płynnej według metody Labaraka na 3 ruble za funt" ${ }^{\prime \prime}$. Do obligatoryjnych administracyjnych środków przeciwcholerycznych podejmowanych $\mathrm{w}$ regionach, gdzie wykryto cholerę, należały między innymi: wyznaczanie tymczasowych szpitali cholerycznych, organizacja kordonów sanitarnych, punktów kwarantanny i budowa baraków cholerycznych ${ }^{42}$. Jednak zalecenie dotyczące tychże przedsięwzięć miały charakter bardzo ogólny, nie zawierały ich szczegółowego opisu ${ }^{43}$. Przy grzebaniu zmarłych na cholerę trzeba było przestrzegać określonych zasad sanitarnych, gdyż podczas tradycyjnych rytuałów pogrzebowych infekcja mogła się rozprzestrzeniać. Dlatego 5 października $1830 \mathrm{r}$. Minister Spraw Wewnętrznych wydal rozkaz zorganizowania osobnych specjalnych cmentarzy dla zmarłych na cholerę: należało je ogrodzić, a doły na groby - wykopać jak najgłębsze i wypełnić wapnem palonym. Krewnym nie wolno było dotykać zmarłych. Ubrania i inne przedmioty należące do zmarłego miały zostać spalone ${ }^{44}$. Ministerstwo Spraw Wewnętrznych wydało Krótką instrukcję rozpoznawania oznak cholery, profilaktyki i środków jej początkowego leczenia, jednak część jej regulacji była pozbawiona sensu, na przykład zabroniono w niej „picia nieczystej wody, piwa i młodego kwasu chlebowego" czy też mieszkania „w mieszkaniach ciasnych, nieczystych, wilgotnych". Większość społeczeństwa nie miała wyboru - piła to, co było dostępne, i mieszkała tak, jak ją na to było stać ${ }^{45}$ (il. 4).

Z powodu cholery tambowski gubernator wstrzymał nabór do wojska i uzyskał na to zgodę Ministra ${ }^{46}$. W Tambowie lokalne rozporządzenie ściśle określało konstrukcję wózka do przewozu chorych na cholerę (czyli „karetki”): miał być wykonany z desek, „wewnątrz tapicerowany filcem, bo chorzy przewożeni zimą w otwartych saniach mogą łatwo się przeziębić i tym samym pogłębić swoją chorobę. Miał mierzyć 3 arszyny ${ }^{47}$ długości, 2 arszyny szerokości i 2 arszyny i 6 werszków ${ }^{48}$ wysokości” ${ }^{49}$. Wózki te powszechnie nazywano „cholerycznymi”. Za dowiezienie chorego do szpitala, lecznicy czy lazaretu przysługiwała opłata (zwrot kosztów),

${ }_{41}$ Трушин, Борьба с холерой, 40.

42 Валерий В. Канищев, Юрий В. Мещеряков, Евгений В. Яковлев, Тамбовский бунт 18302. в контексте холерных кризисов в России ХІХ века (Тамбов: Тамбовский государственный университет им. Г.Р. Державина, 2009), 85.

43 Ibidem, 86.

$44 \quad$ Ibidem, 139.

45 Ibidem, 21-22.

46 Ibidem, 140.

47 W latach 1849-1915 w Rosji urzędowo 1 arszyn $=0,711167$ m, wcześniej wahał się od 0,71 do $0,81 \mathrm{~m}$.

48 Około $4,5 \mathrm{~cm}$.

49 Канищев, Мещеряков, Яковлев, Тамбовский, 123-124. 


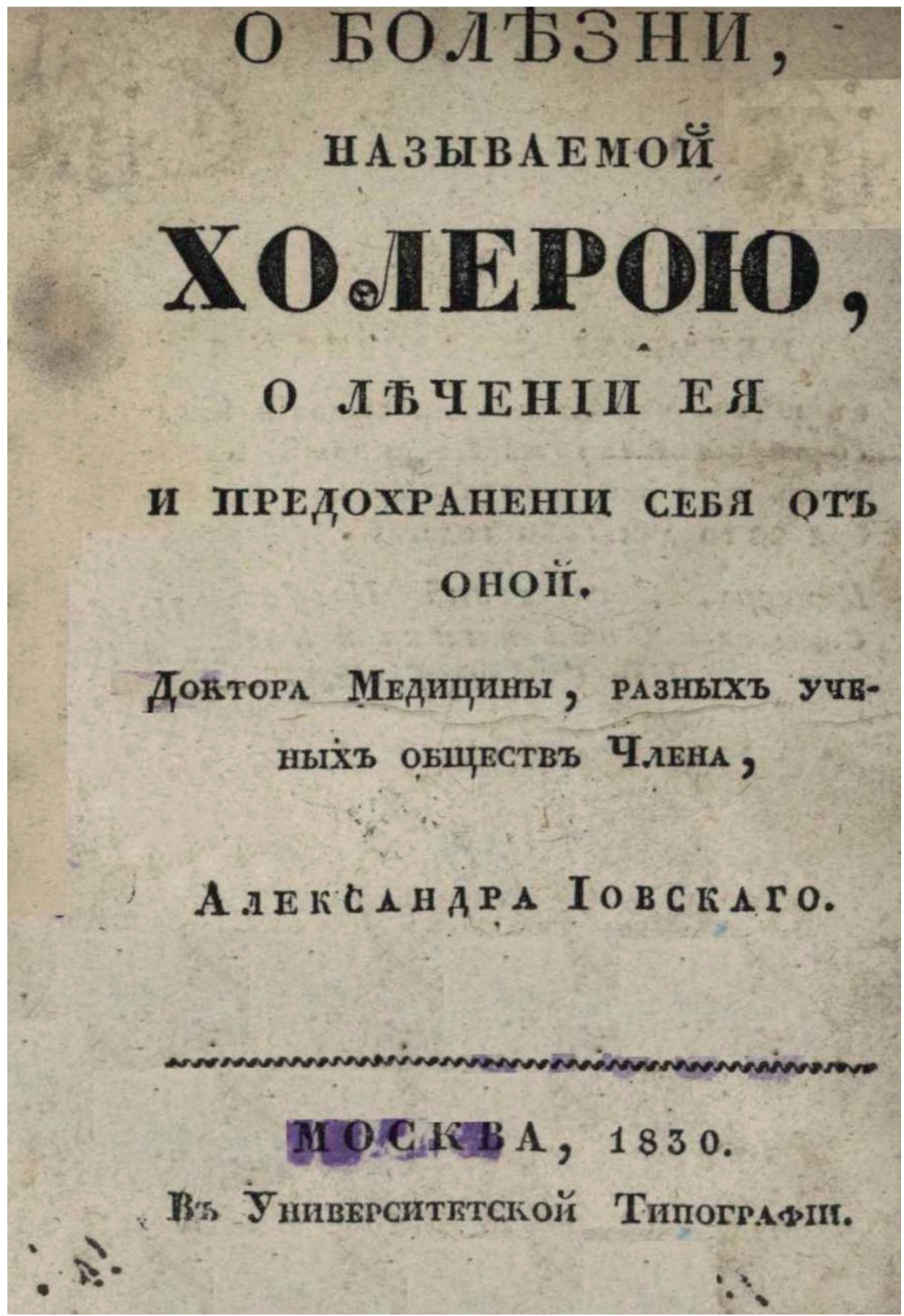

Il. 4. Okładka jednej z licznych broszur o leczeniu cholery, wydana w $1830 \mathrm{r}$. Fot. Zbigniew Landowski 
przy czym szpital nie płacił za transport gotówką, tylko „cholerycznym biletem” o wartości 20 kopiejek, realizowanym później w starostwie ${ }^{50}$.

Szczególną uwagę poświęcono kwarantannie, a raczej punktom kontrolnym. Właśnie one stały się jedną z przyczyn późniejszego niezadowolenia społecznego. Trzeba podkreślić, że przez kwarantannę rozumiano wszystkie środki administracyjne uniemożliwiające lub utrudniające poruszanie się obywatelom i transport dóbr, a więc były to zarówno pobyty na obserwacji przy zastawach, jak i zakazy opuszczania domów, w których ktoś chorował, czy nakazy dezynfekcji zwierząt i towarów itp. Kwarantanną chłopi najczęściej nazywali miejsce pobytu na obserwacji przy rogatce. „Przy głównych drogach komunikacyjnych prowadzących do innych obwodów" polecono ustanowić punkty kontrolne. Jak głosił dekret, „powinny być pod dowództwem godnego zaufania szlachcica, mają liczyć [...], dwóch lub trzech szeregowych lub inwalidów [...] oraz dziesięciu pieszych chłopów”. We wsiach przydrożnych należało rozmieścić „szlabany lub bramy zawsze zamknięte na czas warty" ${ }^{11}$ :

[...] w 1830 r. w guberni smoleńskiej ustanowiono kwarantanny w Kołoczskim, na wjeździe do guberni moskiewskiej (październik 1830 r.), w Juchnowie, na wjeździe do guberni moskiewskiej (styczeń 1831 r.) i w zakładach szklarskich Rasławskiego w Swarskiej, na wjeździe do guberni czernihowskiej. Przy każdym takim punkcie znajdował się lekarz, który dokonywał oględzin wyjeżdżających i przyjeżdżających podróżnych i leczył tych z nich, którzy byli chorzy. Składał on cotygodniowe raporty, z których widać, że przejeżdżających było bardzo wielu, na przykład punkt kontrolny w Swarskiej od 16 do 30 stycznia przejechało 2217 osób i 5093 podwody. W Kołoczskim kwarantannę zlikwidowano 20 marca 1831 r., w zamian ustanowiono dwa punkty obserwacyjne, po jednym w Trojewie i w Masłowce, ale 15 kwietnia przywrócono kwarantannę w Kołoczskim. W miejscu kwarantanny wszystkich ludzi i wszystkie rzeczy obmywano roztworem chlorowanego wapna i opryskiwano/odymiano przy pomocy oxidi manganci nigri i kwasu siarkowego ${ }^{52}$.

Carskie Sioło, gdzie przebywała podczas cholery carska rodzina, zostało w 1830 r. odcięte kordonem. Chronił je batalion gwardii, który miał siedzibę na stacji Iżora, gdzie znajdował się punkt kontrolny kwarantanny ${ }^{53}$.

Organizacja kwarantanny była nadmiernie surowa i bardzo nieprzemyślana, wprost stymulowała nadużycia: urzędnicy z punktów kwarantanny szeroko praktykowali przekupstwo, można było na przykład w ten sposób skrócić czas

\footnotetext{
50 Ibidem, 19.

51 Ibidem, 86-87.

52 Дмитрий Н. Жбанковъ, Холерныя эпидеміи въ Смоленской губерніи 1831-1872 22. (краткій очеркъ) (Смоленскъ: Медико-статистическое отделение Смоленской губернии земства, 1893), 10-11.

53 Иван Р. фон дер Ховен, „Холера в Санкт-Петербурге в 1831 году”, Русская старина 44 (1884): 391.
} 
pobytu na obserwacji z dwóch tygodni do - nawet - dwóch godzin ${ }^{54}$. W całej Rosji tysięczne tabory dostarczające towary oraz okoliczni chłopi jadący z prowizją, sianem i owsem do miast (nie tylko stolicy), wszyscy byli w punktach kwarantanny zatrzymywani i fumigowani ${ }^{55}$. Wszystkie towary i rzeczy podzielono na cztery kategorie, a dla każdej z nich określono własne metody dezynfekcji ${ }^{56}$. Przestrzegano także procedur odkażania przesyłanej korespondencji ${ }^{57}$. W zakresie weterynarii zaproponowano przepędzanie wszystkich zwierząt na posterunkach kwarantanny przez wodę, „gdzie ona jest, a jeśli onej tam nie ma”, to należało je „spryskać roztworem wapna gaszonego lub ługu solnego, ewentualnie roztworem płynnego wapna niegaszonego" 58 .

W związku z blokadą, niszczeniem żywności i towarów podczas dezynfekcji i opóźnieniami dostaw podstawowych artykułów spożywczych ich ceny poszybowały w górę ${ }^{59}$.

W miarę upływu czasu łagodzono przepisy - 14-dniową obserwację, podczas której odzież wszystkich przybyszów i ich rzeczy codziennie myto roztworem wapna chlorowanego, poddawano fumigacji i wentylowano, skrócono do pięciodniowej osobom wyglądającym na zdrowe. Pełna 14-dniowa obowiązywała wyłącznie tych, co do których istniało podejrzenie zakażenia.

W zakresie leczenia chorych na cholerę przede wszystkim uznano za konieczne oddzielenie chorych od zdrowych ${ }^{60}$. Podczas leczenia należało „podawać pacjentowi ciepłe, aromatyczne napoje, krople miętowe z opium, nacierać ciało kamforą lub amoniakiem, terpentyną, winem $\mathrm{z}$ dodatkiem musztardy lub papryki, wodą smołową, na brzuch przyłożyć poszewkę napełnioną gorącym popiołem, rozgrzanym owsem lub otrębami”'11. Lekarze często stosowali kalomel, a na skurcze, bóle żołądka i jelit - leki opiumopochodne ${ }^{62}$, ekstrakt z lulka indyjskiego czy chmielu. Rejestr leków przepisanych przez radę lekarską do leczenia cholery obejmował między innymi: wapno chlorowane, sodę, opium w proszku, kalomel, olejek miętowy, kamforę, magnezję, sproszkowany rabarbar, paprykę roczną, gumę arabską, szafran, gąbkę, sproszkowany korzeń Jateorhiza palmata, pociętą korę krocienia korodajnego Cortex cascarillae, pocięty korzeń Radix calamiarotatici, spirytus salicylowy itp. ${ }^{63}$ Członkowie Rady Lekarskiej uznawali różne metody

54 Константин Н. Токаревич, Татьяна И. Грекова, По следам минувиих эпидемий (Ленинград: Лениздат, 1986), 22.

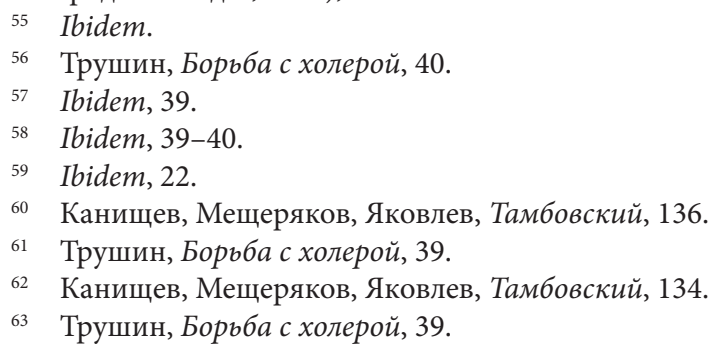


leczenia, często przeciwstawne sobie, ponieważ nie potrafili dokładnie wyjaśnić natury choroby. Za skuteczne uznawano na przykład upuszczanie krwi z ręki lub nogi. W przypadku niemowląt i dzieci zamiast upuszczania krwi stosowano pijawki ${ }^{64}$. Wśród mieszkańców wsi największym zaufaniem cieszył się gorący napar z mięty. Chłopi pili go w dużych ilościach od początku epidemii. Nacierano chorych gorącą wodą. mlekiem, wodą mydlaną itp. ${ }^{65}$ Wszystkim rekomendowano utrzymywanie czystości, higieny osobistej i umiar w jedzeniu ${ }^{66}$. Osoby mające kontakt $\mathrm{z}$ chorymi powinny były myć ręce słabym roztworem kwasu octowego lub podchlorynu sodu. Zalecono im także mycie się ługiem ${ }^{67}$. Ubrania po kontakcie $\mathrm{z}$ chorymi na cholerę należało zdjąć i poddać fumigacji oparami kwasu octowego, siarkowego, azotanowo-chlorowodorowego lub chlorem ${ }^{68}$. Zmarłych należało myć wodą zmieszaną z „niewielką ilością zgaszonego wapna, aby zdezynfekować pot, który pojawił się na ciele chorego podczas jego walki ze śmiercią"69.

Podano przepis na środki do fumigacji: „[...] weź cztery części drobno zmielonej soli kuchennej i dwie części saletry i po ich wymieszaniu wsyp do jakiejś płaskodennej miseczki, a następnie stopniowo dodawaj kwas siarkowy do trzech części, mieszając roztwór drewnianą pałką, i odkażaj cały dom tą mieszanką". Po takiej fumigacji należało szeroko otworzyć wszystkie okna, wietrzyć pomieszczenia przez trzy dni, a następnie izby „wybielić wapnem palonym, a podłogi umyć ugaszonym ługiem"70. Fumigacji poddawano także przesyłki pocztowe i korespondencję: według instrukcji Ministerstwa Spraw Wewnętrznych Z września 1830 r. do ich obróbki używano pary specjalnego roztworu kwasu solnego. Listy i małe paczki były dziurawione, umieszczane na godzinę w szczelnie zamkniętych drewnianych skrzynkach $\mathrm{z}$ otwartym naczyniem z kwasem solnym, a duże worki - nacinane po bokach i fumigowane przez dwie godziny. Książki i inne rzeczy wysyłane pocztą także dezynfekowano zgodnie $z$ regulaminem ${ }^{71}$.

Ważną rolę w życiu wszystkich - chorych i zdrowych - mieszkańców Rosji odgrywały religia i Kościół (cerkiew prawosławna), pełniące funkcje psychoterapeutyczne. Niektórzy badacze wręcz dzielili społeczności (np. mieszkańców Moskwy w 1830 r.) na trzy grupy: biorących udział w zamieszkach, samoizolujących się i tych, którzy szukali pocieszenia w kościołach ${ }^{72}$. Niekiedy społeczne życie religijne przyczyniało się do masowych zachorowań. Na przykład

64 Канищев, Мещеряков, Яковлев, Тамбовский, 133.

65 Ibidem, 134-135.

66 Ibidem, 136.

67 Ibidem.

68 Ibidem.

69 Трушин, Борьба с холерой, 40.

70 Ibidem.

71 Канищев, Мещеряков, Яковлев, Тамбовский, 138.

72 Roderick E. McGrew, Russia and the Cholera, 1823-1832 (Madison: University of Wisconsin Press, 1965), 76. 
8 sierpnia 1830 r. choroba ponownie pojawiła się w Gruzji, ale nie została prawidłowo zidentyfikowana, zdiagnozowano ją dopiero 13 sierpnia, a według M. Gamba, ówczesnego konsula francuskiego w Tyflisie, „w tym czasie prawie wszyscy mieszkańcy miasta udali się w procesjach do kościołów, aby uspokoić, jak mieli nadzieję, Boski gniew, i od tego momentu choroba stała się powszechna: zmniejszyła liczbę mieszkańców miasta z 30 do 8 tysięcy"73. Zdarzały się też przypadki, że kler prawosławny rozpowszechniał teorie spiskowe: zidentyfikowany przez władze za rozsiewanie takich pogłosek pop z cerkwi św. Barbary w Tambowie „zobowiązał się [...] do wykonania wszystkich rozkazów rządu, chociaż stwierdził: «jeszcze nie widzieliśmy pojawienia się cholery w naszej parafii»" ${ }^{4}$.

W Moskwie, rządzonej (w sferze religijnej) przez metropolitę Filareta (Drozdowa), konfesyjne życie publiczne nie zamarło: odbywały się nabożeństwa i procesje. Już 18 września 1830 r. patriarcha Filaret próbował uspokoić swoją owczarnię słowami ${ }^{75}$ : „Nie patrzcie wielkimi oczami strachu, które zwykle widzą to, czego nie ma, i nie widzą tego, co jest: patrzcie bystrym i przenikliwym wzrokiem odwagi, wnikliwego rozeznania i roztropnej ostrożności" ${ }^{\prime \prime 6}$. O współpracy władz świeckich i kościelnych świadczy rozporządzenie Metropolity Moskiewskiego i Kołomieńskiego Filareta skierowane do Moskiewskiego Świętego Konsystorza O przekonywaniu ludu, iż podczas zagrożenia publicznego nie należy ulegać przygnębieniu ani brać udziału w zamieszkach z 11 października 1830 r.: „Należy przykazywać wszędy księżom, aby przy każdej nadarzającej się okazji zachęcali mieszczan do starannego i wiernego stosowanie środków zapobiegawczych i medycznych przeciwko chorobom zakaźnym oraz wspieranie takich sugestii zrozumiałym rozumowaniem, świadectwami i przykładami [...]"77. I metropolita, i Synod współdziałali z władzami w celu uspokojenia umysłów wiernych, zasiania w nich nadziei i wiary. W 1831 r. ukazało się orędzie Świętego Synodu: Pasterskie wezwanie do prawosławnych chrześcijan dotyczące cholery i stosunku do niej oraz do lekarzy ${ }^{78}$.

W Ławrze i Siergijewie Posadzie w 1830 r. oraz w pierwszej połowie $1831 \mathrm{r}$. nie stwierdzono cholery. Pierwsze jej przypadki opisano dopiero w czerwcu $1831 \mathrm{r}^{79}$, co - biorąc pod uwagę rzesze pątników - było z pewnością rezultatem

73 Kotar, Gessler, Cholera, 35 .

74 Канищев, Мещеряков, Яковлев, Тамбовский, 146-147.

75 Иван Н. Корсунский, „Покров милости Божией над Лаврою Преподобного Сергия и Сергиевым Посадом во времена губительных болезней”, Богословский вестник 10, т. 3 (1892): 94.

76 Сочинения Филарета, митрополита Московского и Коломенского: Слова и речи, ň. 1-5 (Москва: тип. А.И. Мамонтова и Кํ, 1873-1885), 3.

77 Москва в эпоху Николая I. 1825-1855: Документы и материалы. Кн. 1, ред. Елизавета Д. Алексеева (Москва: Издательство ГБУ „ЦГА Москвы”, 2013), 542-543.

78 Трушин, Борьба с холерой, 40.

79 Татьяна В. Соломай, Марионелла А. Сырцова, „Эпидемиологические особенности холеры в Сергиевом Посаде московской области в XIX веке”, Санитарный врач 1 (2019): 71. 
terminowego wykrywania i izolowania pacjentów z cholerą, czyli efektywnej medycznej działalności profilaktycznej. Punkty kwarantanny zorganizowano już na początku 1830 r. - jeden z nich znajdował się przy ulicy Perejasławskiej, tam podejrzewani o chorobę pozostawali na obserwacji przez trzy dni, a następnie byli przenoszeni do budynku starego hotelu, gdzie przebywali przez kolejne pięć dni ${ }^{80}$. Innym ważnym czynnikiem, który prawdopodobnie odegrał kluczową rolę w zapobieganiu epidemii, było zaopatrzenie w wodę pitną w Posadzie: $w$ przeciwieństwie do innych terytoriów, gdzie wykorzystywano do tego celu wody powierzchniowe, mieszkańcy Siergijewa Posada głównie pili wodę źródlaną i z głębokich, chronionych studni ${ }^{81}$.

Cerkiew aktywnie działała nie tylko podczas epidemii, ale i zaraz po niej - brała udział w organizacji radosnych uroczystości z okazji odejścia zarazy:

Krzemieńczuk, 2 lutego. Nasi przychylni nam rodacy wiedzą już z raportów, że katastrofa, która dotknęła większość Rosji, nie minęła i naszego miasta. Od 18 listopada ubiegłego roku mieliśmy cholerę i trwała około dwóch miesięcy. W tym czasie spośród 347 osób, które zachorowały, 141 wyzdrowiało, 206 zmarło, ale od 11 stycznia choroba, dzięki miłosierdziu Bożemu, całkowicie ustała i nie było ponownie chorych. Dlatego szlachta i obywatele miasta, chcąc spełnić święty obowiązek wdzięczności i zanieść serdeczne prośby do Pana Boga, który zbawił ich od grożącego im niebezpieczeństwa, skierowała zaproszenie do czcigodnego przełożonego swego, Pana generała kawalerii, generał-adiutanta, wojskowego gubernatora małorosyjskiego, księcia Nikołaja Szewczenki Riepnina, do przyjazdu do Krzemieńczuka, aby wziął udział w uroczystych modłach. [...] 1 lutego w tutejszej katedrze złożono Panu Bogu modlitwę dziękczynną i proklamację wieloletnią dla Jego Cesarskiej Mości i całego Cesarskiego Najjaśniejszego Domu. Wieczorem szlachta i kupiectwo miasta Krzemieńczuk wydały wspaniały bal i kolację w sali Zgromadzenia szlacheckiego, w którym uczestniczyło [...] ponad trzysta osób obu płci i który trwał do trzeciej nad ranem. Dom Zgromadzenia szlacheckiego był iluminowany ${ }^{82}$.

Terapeutyczną rolę wypełniał nie tylko Kościół, ale przede wszystkim władze i sterowana przez nie prasa. Uspokajanie nastrojów, pobudzenie nadziei na poprawę sytuacji zajmowało umysły administratorów państwa i jego aparat, a także kierowanych przezeń ręcznie periodyków. Przykładem podtrzymywania na duchu, dodawania otuchy mieszkańcom guberni połtawskiej przez gubernatora Jego Cesarskiej Wysokości generała-adiutanta, wojskowego gubernatora małorosyjskiego, generała kawalerii księcia Riepnina, jest apel opublikowany 16 września 1830 r. (il. 5):

\footnotetext{
$80 \quad$ Ibidem, 73.

$81 \quad$ Ibidem, 77.

82 Сюверная Пчела 53 (9 III 1831 r.): [1], b.p.
} 


\section{Cok̂erbcercie.

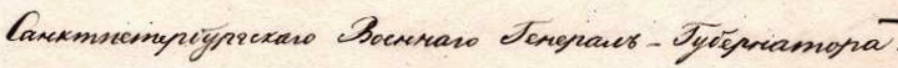

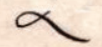

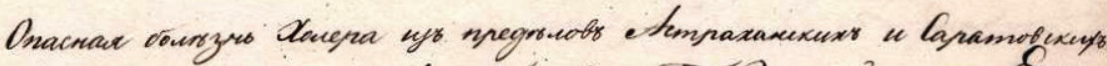

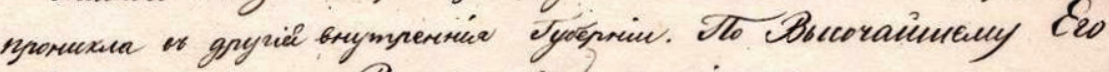

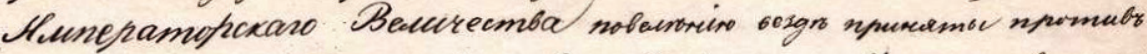

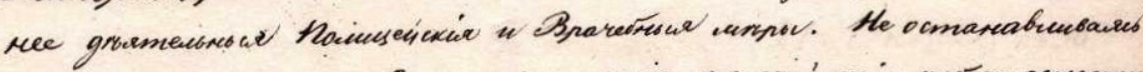

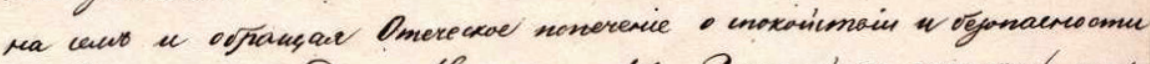
cai Imanuser. Tocyoaps Alunepamofor Boccoraciece noscursmb couf-

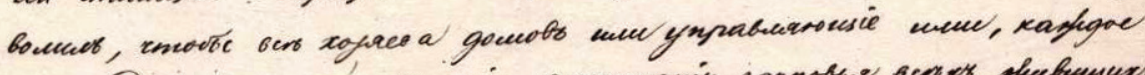

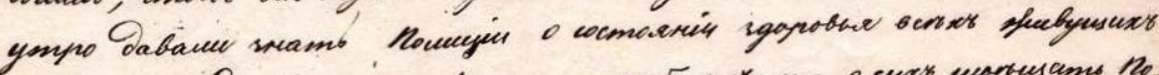

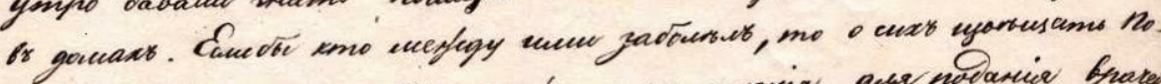

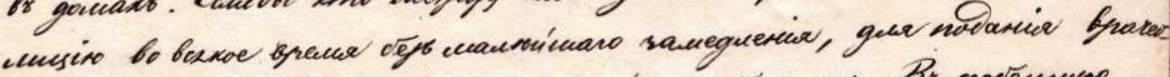

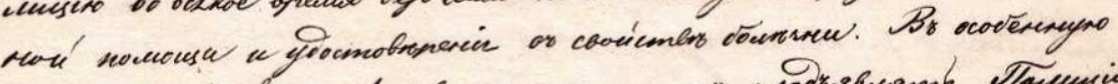

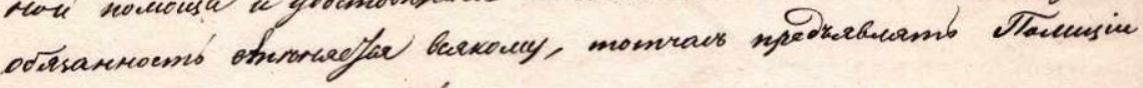
oor yelequecuxts croponocmugfero.

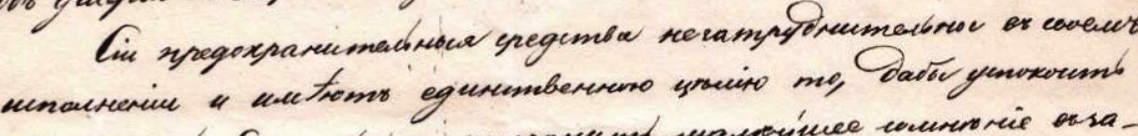

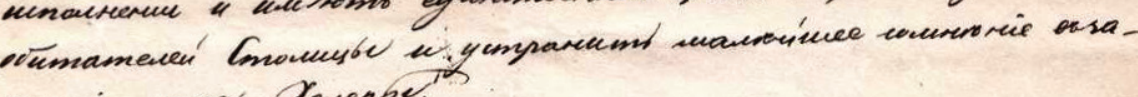
Hecorier ingal Xouepbe.

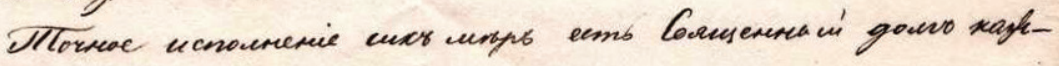

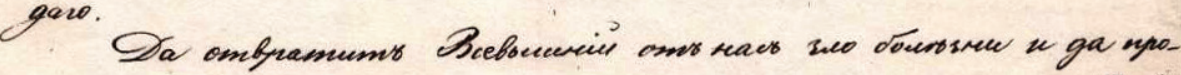

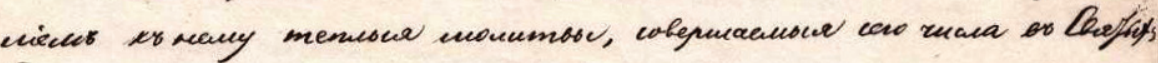
Sio seproalt.

Il. 5. Oryginał jednego z rozporządzeń władz gubernialnych

Fot. Zbigniew Landowski

1. Choroba, niedaleko od nas rozprzestrzeniona, nie jest zakaźna od dotyku, jak dżuma, zatem nie jest tak groźna, jak morowa zaraza.

2. Choroba ta poddaje się wyleczeniu, jeśli od razu ją się temu leczeniu poddaje. Zapewniam o tym wszystkich mieszkańców połtawskiej guberni, jednak przy okazji przedstawiam im rady, jak przed nią się chronić i dlatego proszę ich o przestrzeganie każdej z nich i wszystkich razem:

1) $Z$ przekonaniem opierajcie się na nadziei w miłosierdzie Boże i wstawienictwo za nas Zbawiciela naszego, odwracającego od nas wszelkie zło.

2) Wierzcie głęboko w ojcowską opiekę najmiłościwiej nam panującego Suwerena naszego, który już zwrócił swoją szczególną uwagę na kwestię powstrzymania choroby, a także w to, że wypełniając najwyższą wolę Jego Cesarskiej Wysokości, 
wykorzystam wszystkie środki, aby nie dopuścić do wtargnięcia onej choroby do guberni połtawskiej.

3) W związku z tym bądźcie spokojni, weseli i zajmujcie się swoimi obowiązkami, sprawami i pracami jak uprzednio.

4) Ubierajcie się, jak można, najcieplej, szczególnie wychodząc na świeże powietrze w wilgotną pogodę. Jak najczęściej należy prać koszule i spodnie.

5) Chaty (domy) utrzymujcie w czystości, porządku i ogrzewajcie je. Należy wywozić z nich śmieci i uprzątać nawóz i inne nieczystości z podwórzy.

6) Nie wolno jeść pokarmów surowych i zepsutych, szczególnie arbuzów, melonów, jabłek, śliwek, i wszystkiego, co może być przyczyną fermentacji w żołądku.

7) Nie powinno się spać na świeżym powietrzu.

8) W chatach (domach) nie zbierajcie się licznie i nie nocujcie w nich tłumnie, szczególnie jeśli są zawilgocone.

9) Nie spożywajcie w nadmiarze napoi alkoholowych, ale miarka nalewki z piołunu lub dziurawca jest jak należy wskazana: dorosłym podajemy miarkę nalewki zmieszaną z trzema miarkami gorącej wody, dziennie pijemy po jednej miarce takiego napoju, a małoletnim jego podawanie nie jest konieczne dokumentnie.

10) Nie wychodźcie z domu na czczo, przed wyjściem należy zjeść kawałek posolonego chleba $\mathrm{z}$ cebulą lub czosnkiem.

11) Pijcie wodę dziegciową (smołową), która wzmacnia siły, poprawia wydzielanie żółci; aby ją zrobić, należy do wiadra wrzącej wody wlać pół kwarty dziegciu i mieszać, póki nie ostygnie. Napój ten - w tym właśnie przypadku [cholery] - jest bardzo zdrowy i przydatny. Należy pić jak najmniej surowej wody, kwasy owocowe i żur na zimno są szkodliwe i nie należy pić ich w ogóle ${ }^{83}$.

Prasa pełniła funkcję informacyjną, regularnie przekazując wiadomości o epidemii, na przykład w dziennikach (m.in. Сюверная Пчела) w 1831 r. codziennie podawano liczbę zachorowań, wyzdrowień i śmierci na cholerę, a także osób nadal leczonych w różnych regionach Rosji. Raporty te różniły się datami ich przekazywania (z niektórych regionów kraju z dużym opóźnieniem), prawdopodobnie też z powodu cenzury podawały liczby zaniżone.

Najczęściej w tych informacjach przedrukowywano raporty z Ведомость о состоянии города Москвы, potocznie nazywanych "gazetą choleryczną", oficjalnego biuletynu wydawanego przez władze Moskwy od 23 września $1830 \mathrm{r}$. do 6 stycznia 1831 r. w okresie epidemii cholery, łącznie ukazało się 106 numerów. Po zakończeniu epidemii przestano ją wydawać. Podobne „raporty” („gazetę choleryczną") wydawano w Petersburgu ${ }^{84}$ (il. 6).

83 Ахшарумов, Холера въ, 213-214.

84 Медицинская Литература, w Большая Медицинская Энизилопедия, za: https://web. archive.org/web/20111020163243/http://bigmeden.ru/article/Медицинская_Литература, dostęp: 29 XI $2021 \mathrm{r}$. 


\section{BB A (1) M C C}

- состоянIи СТоличHATO ГOPOAA

C A H I T II E T E P БУ Р T.

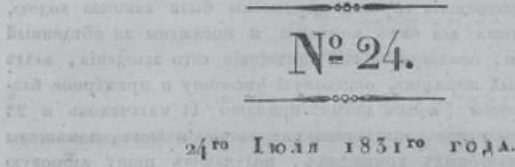

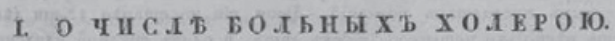

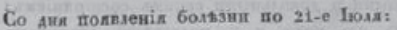

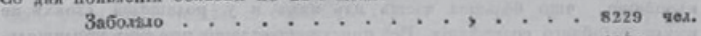

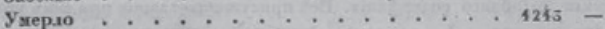

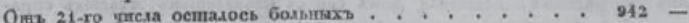

Br. mesenie cymoxz 22-ro hosr:

Забольмо ............. $17-$

Вездоровало ............. 128 .

Уяерло ............... 33 .

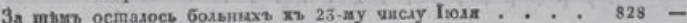

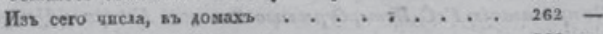

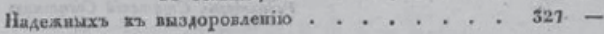

II. Р А C II O Р I

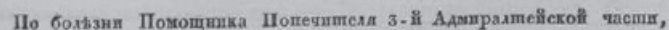

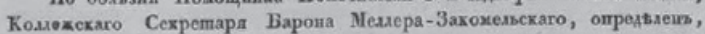

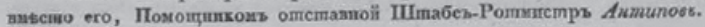

\section{II O 正 $\mathrm{E}$ Р T В О В $\Lambda$ H I 月.}

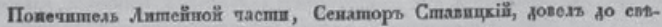

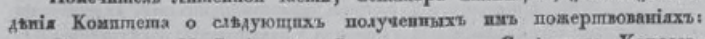

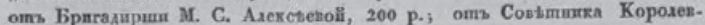

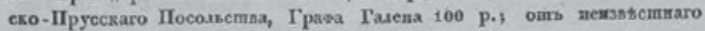
пить рубей серебромъ.

Il. 6. Gazeta choleryczna z Sankt-Petersburga Ведомость о состоянии столичнаго города Санкт-Петербурга 24 (1831)

Fot. Zbigniew Landowski

Na przykład fragment raportu z Сюверной Пчель ze stycznia 1831 r. (wyciąg z Raportu o stanie Miasta Moskwy nr 96 i 97 z dn. 27 i 28 grudnia [1830]) brzmiał następująco:

26 grudnia umarło z powodu różnych chorób 7 osób. Na cholerę chorowało 91 osób, nowych zachorowań - 13, zmarło 12, w szpitalach przebywają 92 osoby. W lazaretach państwowych przebywa 63 pacjentów, zachorowało w ciągu ostatniej doby 10 osób, zmarło 4 pacjentów, leczy się 69 pacjentów. 27 grudnia umarło 
w Moskwie na różne choroby 13 osób. Na cholerę leczyło się 92 pacjentów, zachorowało 14 , wyzdrowiało 5 , zmarło 6 , na leczeniu pozostaje 95 . W lazaretach państwowych pozostawało 69, zachorowało 14, wyzdrowiało 4, zmarło 9, zostało na leczeniu $70^{85}$.

W dalszej część raportu podano (w zbliżony sposób) dane z różnych innych regionów Cesarstwa. Pod koniec epidemii pojawiały się też meldunki lokalnych władz o wycofaniu się cholery z ich regionów (miast itd.), między innymi 23 stycznia 1831 r. „Minister Spraw Wewnętrznych, generał-adiutant, hrabia A.A. Zakriewskij ogłosił, że panująca w Wiackiej guberni, w powiatach Jełabużskim i Małomyżskim, epidemiczna choroba cholera z łaski Najwyższego zupełnie skończyła się i gubernia ta znajduje się obecnie w pomyślnej sytuacji" ${ }^{\prime 6}$. Czasami dochodziło do powrotów zarazy na terytorium uznanym już za bezpieczne:

Odessa, 12 czerwca. Choroba epidemiczna z objawami cholery pojawiła się ponownie w Odessie, w różnych powiatach guberni Chersońskiej i obwodu Besarabskiego. 9 czerwca w Odessie zachorowało 6 osób, z których 3 zmarły tego samego dnia; 7 osób zachorowało 10 czerwca, z tego 1 zmarła tego samego dnia; 11 osób zachorowało 11 czerwca, z których 3 zmarły tego samego dnia, poza tym zmarło 2 pacjentów $\mathrm{z}$ uprzednio chorych. Aby powstrzymać rozprzestrzenianie się epidemii, lokalne władze podjęły aktywne działania. W celu zapewnienia opieki lekarskiej chorym powołano specjalny Szpital. Oprócz miasta, choroba ta pojawiła się także w kwarantannie portowej: 6 i 10 czerwca zmarły tam 3 osoby, ich śmierć, według opinii lekarz, była spowodowana epidemią ${ }^{87}$.

Od czasu do czasu podawano też sumaryczne raporty, na przykład w numerze z 7 maja 1831 r. ${ }^{88}$ podano następujące liczby:

Tabela 1. Raport o sytuacji epidemicznej w wybranych guberniach Rosji z 7 maja 1831 r.

\begin{tabular}{|c|c|c|c|c|}
\hline $\begin{array}{c}\text { Gubernie } \\
\text { (wybrane) }\end{array}$ & $\begin{array}{c}\text { Liczba } \\
\text { zachorowań }\end{array}$ & $\begin{array}{c}\text { Liczba } \\
\text { wyzdrowień }\end{array}$ & Liczba zmarłych & $\begin{array}{c}\text { Liczba nadal } \\
\text { chorujących }\end{array}$ \\
\hline $\begin{array}{c}\text { połtawska (stan } \\
\text { na 27 marca) }\end{array}$ & 531 & 174 & 340 & 17 \\
\hline $\begin{array}{c}\text { kijowska (stan } \\
\text { na 19 kwietnia) }\end{array}$ & 5276 & 2378 & 2799 & 80 \\
\hline $\begin{array}{c}\text { podolska (stan } \\
\text { na 1 kwietnia) }\end{array}$ & 12072 & 6352 & 5286 & 434 \\
\hline
\end{tabular}

\footnotetext{
85 Спверная Пчела 4 (1831): [2], b.p.

86 Спверная Пчела 18 (1831): [1], b.p.

87 Сюверная Пчела 141 (1831): [2], b.p.

88 Спверная Пчела 100 (1831): [2], b.p.
} 


\begin{tabular}{|c|c|c|c|c|}
\hline $\begin{array}{c}\text { Gubernie } \\
\text { (wybrane) }\end{array}$ & $\begin{array}{c}\text { Liczba } \\
\text { zachorowań }\end{array}$ & $\begin{array}{c}\text { Liczba } \\
\text { wyzdrowień }\end{array}$ & Liczba zmarłych & $\begin{array}{c}\text { Liczna nadal } \\
\text { chorujących }\end{array}$ \\
\hline $\begin{array}{c}\text { wołyńska (stan } \\
\text { na 16 kwietnia) }\end{array}$ & 5976 & 1579 & 3867 & 530 \\
\hline $\begin{array}{c}\text { grodnieńska (stan } \\
\text { na 4 kwietnia) }\end{array}$ & 288 & 45 & 173 & 70 \\
\hline $\begin{array}{c}\text { wileńska (stan } \\
\text { na 23 kwietnia) }\end{array}$ & 371 & 14 & 133 & 224 \\
\hline $\begin{array}{c}\text { mińska (stan } \\
\text { na 22 kwietnia) }\end{array}$ & 1183 & 408 & 621 & 154 \\
\hline
\end{tabular}

* Data przybliżona (tu i dalej) - w różnych regionach guberni daty raportów są różne, w przybliżeniu różnice sięgają 2 tygodni.

Źródło: opracowanie własne na podstawie danych z raportu Ministra Spraw Wewnętrznych hrabiego A.A. Zakrijewskiego, Спверная Пчела 100 (1831): [2], b.p.

Publikowano też informacje o rozprzestrzenianiu się cholery w innych krajach: w numerze z 18 grudnia 1831 r. podano, powtarzając treść listu nadesłanego z Luksoru w Egipcie, że: „Cholera, która pochowała około 30000 ludzi w Kairze, zbliża się do Luksoru, niewielkiej wioski liczącej 800 mieszkańców, 5 września umarło tam jeszcze od 10 do 12 osób”. A także - „Przed południem 12 grudnia w Wiedniu było 4046 chorych na cholerę, 2037 osób wyzdrowiało, a 1936 zmarło. [...] W 19 okręgach Galicji, w 46 miejscach, do 19 listopada było 259805 chorych, wyzdrowiało 162 083, zmarło 97654 osób" ${ }^{39}$.

Niektóre komunikaty miały odmienną naturę, były meldunkami „oddolnymi” i przybierały charakter, jak byśmy to dziś określili, „sponsorowanego” reportażu, będącego ewidentnie działaniem socjotechnicznym, uwypuklającym ścisłe współdziałanie władz i Kościoła:

Niżyn. 14 maja. Jego Jaśnie Pan małorosyjski gubernator wojskowy, książę Nikołaj Grigoriewicz Repnin, zapewniając prawdziwą ojcowską opiekę nad powierzonym zarządowi jego małorosyjskiemu ludowi, odwiedzał osobiście wszystkie miejsca, w których panowała cholera, aby wydawać odpowiednie rozkazy. Gdy ta choroba pojawiła się w mieście Niżyn, Jaśnie Pan pospieszył do tego miasta, a po zbadaniu szpitali pocieszył cierpiących, zatwierdził środki podjęte przez władze grodu $z$ powodu epidemii i wydał niezbędne polecenia. Następnie, zgodnie z Jego wolą i rozkazem, archimandryta Platon z całym tutejszym duchowieństwem odprawił w klasztorze Zwiastowania w Niżynie w obecności Jaśnie Pana, urzędników wojskowych, cywilnych i licznych mieszczan i wieśniaków uroczyste nabożeństwo, modląc się do Najwyższego o klęskę zarazy i o zesłanie Boskiej, Świętej Pomocy w tym nieszczęściu, które nas spotkało. Po poświęceniu wody archimandryta Platon wraz z Jaśnie Panem gubernatorem odwiedzili szpital, w którym zostali powitani przez szefa policji, głowę grodu i lekarzy. Archimandryta Platon poświęcił 
szpital i cierpiących wodą święconą, a kapłani, każdy w swojej parafii w całym mieście, poprowadzili procesje $\mathrm{e}^{90}$.

W prasie publikowano też materiały „ku pokrzepieniu ducha”, o poświęceniu personelu medycznego: „Młody lekarz Wadim Passek (Вадим Пассек), bezinteresownie oddając się do dyspozycji Komitetu Cholerycznego, przeprowadzał na sobie eksperymenty [...], których pomyślny wynik [...] przyciągnął więcej ochotników"91 albo ,jak poinformował 5 lutego Minister Spraw Wewnętrznych, generał-adiutant hrabia A.A. Zakriewskij”, właściciel apteki w Berdyczowie, aptekarz Streckij, z powodu rozprzestrzenienia się w mieście cholery, kierując się dobrem powszechnem, zobowiązał się dostarczać nieodpłatnie leki przeciw cholerze na recepty przeznaczone dla szarż wojskowych"92.

Tak kompleksowe działania struktur państwowych - administracji, służb, mediów i cerkwi - były reakcją na to, w jaki sposób całe społeczeństwo postrzegało samą chorobę i środki podjęte przez państwo. Najpierw wybuchła panika. A panice towarzyszyły plotki. Choroba budziła przerażenie, bo uważano ją najpierw za dżumę ${ }^{93}$. Potem wywoływała grozę ze względu na wysoką śmiertelność, przy czym śmierć z powodu cholery łączyła się z odrażającymi męczarniami (stąd nazywano ją "psią zarazą"). Jeszcze później popłoch budził już sam widok „cholerycznych wózków” (czarnych, wyściełanych wozów do przewozu chorych na cholerę do wydzielonych szpitali), często podążających z zarażonymi w konwoju policji. Policjanci wdzierali się do domów tych biedaków, o których wiadomo było, że są chorzy, zabierali ich siłą i odwozili do lazaretów. I. Jakunin, świadek tych porządków, napisał: „[...] zdarzało się, że w drodze do szpitala, który był poza miastem [...] ludzie umierali w tych wozach. [...] Ogólnie rzecz biorąc, kiedy te wózki choleryczne spotkali na ulicach chłopi lub mieszczanie, jeśli byli na koniach, zawracali i pędzili, gdzie koń poniesie; a piesi rzucali się skryć, gdzie popadło - w cudze furtki i bramy" ${ }^{44}$. „Wózki choleryczne” stały się symbolem nieuniknionej śmierci ${ }^{95}$.

Panika wynikała też z obawy przed zatruciem: powszechnie krążyły pogłoski o trucicielach, którzy działali w całej Rosji latem 1831 r. i „zatruwali ludzi, wypuszczając truciznę do studni, żywności, rzek i zbiorników, pól i ogródków warzywnych. Przestraszeni ludzie zabijali deskami studnie, bali się kupować jedzenie w sklepach i łapali na ulicach każdego, kogo zachowanie budziło ich podejrzenia o trucie" ${ }^{96}$.

90 Спверная Пчела 126 (1831): [2], b.p.

91 Вадим Васильевич Пассек, „Три дня в Москве во время холеры”, Молва 27-29 (1831).

92 Спверная Пчела 28 (1831): [1], b.p.

93 Kotar, Gessler, Cholera, 92.

94 Канищев, Мещеряков, Яковлев, Тамбовский, 124.

95 Ibidem, 123-124.

96 Александр К. Егоров, „Распространение слухов об отравлении во время эпидемии холеры 1830/1831 гг. в России: случай в Пскове”, Актуальные проблемы гуманитарных и естественных наук 8, часть 1 (2016): 117. 
Niektóre posunięcia władz potęgowały złe nastroje, na przykład Ministerstwo Spraw Wewnętrznych w okólniku, w którym instruowało, jak przeciwstawić się cholerze, zakazało „oddawać się gniewowi, strachowi, udręce, przygnębieniu i niepokojowi ducha" ${ }^{97}$. Jeszcze bardziej wzburzała bezczynność i apatia aparatu państwowego: „A rząd śpi: nie podejmuje żadnych działań, aby uspokoić umysły”. Ludność nie bała się już samej cholery, ale podjętych „restrykcyjnych” środków ${ }^{99}$.

$\mathrm{Na}$ wsi w opowieściach ludowych zaczęto cholerę „utożsamiać ze złą staruszką o wykoślawionej twarzy" ${ }^{100}$. Przedstawiano ją też jako metaforyczny wiatr przelatujący nad wioskami, który symbolizował „ogromny, czarny ptak z wężowymi głowami i ogonem”. Ta maszkara miała latać jedynie w nocy, a „tam, gdzie dotknie żelaznym skrzydłem wodę"101, wybuchała zaraza. Na Ukrainie bajano, iż to starucha „w czerwonych butach, która może chodzić po wodzie, bez przerwy wzdycha i biega krzycząc nocą po wsiach [...], a w domu, w którym przenocuje, nie przeżyje ani jedna osoba"102.

Panika i plotki jeszcze bardziej zwiększyły liczbę ofiar ${ }^{103}$, chociaż wielu zaprzeczało w ogóle istnieniu tej plagi, twierdzono, że została wymyślona dla własnych korzyści przez złych ludzi itp. ${ }^{104} \mathrm{~W}$ Tule „wśród ludu krążyły straszne plotki, że rozkazano wyniszczyć zwykłych ludzi, aby było ich mniej, dlatego lekarze wrzucają do studni trujące proszki, a zdrowi ludzie są lapani hakami na ulicy i wywożeni do «cholerycznych baraków», z których nikt nigdy nie wraca; tam są zasypywani wapnem i grzebani żywcem” ${ }^{105}$. Z kolei żandarmeria z Władymira donosiła przełożonym, iż „ostatnio powszechnie rozeszła się plotka, że cholerę rozprzestrzeniają wszędzie źli ludzie, przekupieni przez Polaków, Francuzów i Turków, którzy zatruwając studnie i zapasy żywności, powodują śmierć mieszkańców pod postacią cholery"106. Wątek Polaków przewijał się przez wiele plotek i słuchów - wynikał ze zbieżności w czasie: właśnie tłumiono powstanie listopadowe, część wojsk carskich zdążyła wrócić do Rosji, gdy tam rozprzestrzeniała się cholera, a na Wołyniu, gdzie toczono walki, wielu rosyjskich żołnierzy zapadało na tę zarazę. Stąd nie tylko czerń, ale i ludzie wykształceni uważali, że istnieje związek pomiędzy tymi zdarzeniami. Choć cholera pojawiła się w Rosji w 1829 r., już przed wybuchem powstania, to jednak stała się epidemią dopiero w 1830 r. i trwała w europejskiej części Rosji w przybliżeniu do końca 1831 r.

\footnotetext{
97 Токаревич, Грекова, По следам, 21-22.

98 Никитенко, Записки, 58.

99 Канищев, Мещеряков, Яковлев, Тамбовский, 144.

100 Холера в Москве (1830), т. 3.

101 Ibidem.

102 Ibidem.

103 Токаревич, Грекова, По следам, 21-22.

104 Никитенко, Записки, 58.

105 Канищев, Мещеряков, Яковлев, Тамбовский, 286.

106 Александр К. Егоров, „«Это, видно, Польша подкупила докторов так морить...»: к вопросу об источниках возникновения агрессивных слухов во время эпидемии холеры 1830/1831 гг. в России”, Научныцй журнал 8 (2016): 32.
} 
„[...] widać, że Polska przekupiła lekarzy, żeby nas zarazić; [...] Niemców, Polaków, Francuzów - wszyscy oni byli z Petersburga, wyłapano ich i umieszczono w wartowni za to, że wrzucali arszenik do kwasu chlebowego [...]"107. Na ulicach podczas zamieszek „krzyczą przeciw Niemcom, lekarzom i Polakom, grożą im śmiercią” ${ }^{108}$. We wsi Moczyłki w powiecie Lebiedjańskim chłopi wzięli właściciela ziemskiego Kliszyna za „Polaka”, który „wrzucił do wody mieszek z trucizną” i pobili go ${ }^{109}$.

Tymczasem zarazę na ziemie polskie przyniosło właśnie rosyjskie wojsko podczas dławienia powstania listopadowego:

W Prusach pierwsze zachorowania zanotowano w takich miastach, jak Królewiec, Gdańsk i Berlin. W 1831 r. Gdańsk liczył 55000 mieszkańców. Tylko w 1831 r. zachorowało na cholerę 1471 osób, z tego zmarło 1076. Nowy wybuch epidemii w 1832 r. pochłonął jeszcze więcej ofiar. W sumie w latach 1831-32 w Prusach zmarło na cholerę około 41000 ludzi. Między innymi filozof Georg Hegel, pruski marszałek von Gneisenau oraz pisarz i teoretyk sztuki wojskowej generał Carl von Clausewitz. Jeszcze w 1837 r. ponownie choroba nawiedziła miasto. Tym razem ofiarą cholery było prawie 500 osób, w tym grupa polskich flisaków ${ }^{110}$.

I chyba ironią losu można nazwać to, że także tu, na ziemiach polskich, reakcje społeczne był podobne: „Bogaci mieszczanie wyjeżdżali do swoich posiadłości wiejskich, gdzie odizolowani od miasta byli bardziej bezpieczni”"11, a wśród biedoty i nie tylko „krążyła [...] teoria spiskowa mówiąca o celowym sprowadzeniu choroby, aby wyniszczyć niższą klasę społeczną, gdyż ona najbardziej i najczęściej chorowała. A lekarze mieli im [bogatym - Z.L.] pomagać w wytępieniu proletariatu"112.

Konspiracyjne spekulacje krążyły wówczas po całej „zarażonej” Europie i można by nie przydawać im wagi, gdyby nie fakt, że opowieści o podobnej treści były prawdopodobnie jedną z przyczyn zamieszek i buntów cholerycznych, między innymi rosyjskich osadników wojskowych w lipcu $1831 \mathrm{r}$. Tuż przed ich wybuchem władzom donoszono, że „robotnicy wracający z Petersburga rozśrodkowali się, i głoszą, że wypędzili cholerę ze stolicy i że nieźle byłoby zająć się tym też tutaj $[. . .]^{\prime 113}$. Przez „wypędzoną cholerę" rozumieli pobitych lekarzy, urzędników, dowódców i cudzoziemców, domniemanych spiskowców.

\footnotetext{
107 Ibidem, 33.

108 Никитенко, Записки, 58.

109 Канищев, Мещеряков, Яковлев, Тамбовский, 145.

110 Tadeusz Zajączkowski, „Epidemia cholery w Gdańsku i Europie w latach 1831-1832”, Gazeta AMG [obecnie nosi nazwę Gazeta GUMed] 1 (2017): 27, za: https://journals.viamedica.pl/ gazeta_amg/issue/view/3866, dostęp: 29 XI 2021 r.

111 Ibidem.

112 Ibidem

113 Егоров, Это, видно, 33.
} 
Zamieszki i bunty - najbardziej drastyczna manifestacja paniki - przetoczyły się falą przez kilka regionów Rosji w okresie letnim $1831 \mathrm{r}^{114}$

Petersburg, 20 czerwca $1831 \mathrm{r}$.

Miasto jest niezadowolone z rozporządzeń rządu; Najjaśniejszy Pan opuścił stolicę. Członkowie Rady Państwa również prawie wszyscy wyjechali. W Generalnym Gubernatorze nie ma co pokładać nadziei. Lazarety są urządzone w taki sposób, że stanowią jedynie miejsce przejściowe pomiędzy domem a grobem. W każdej części miasta wyznaczani są opiekunowie, ale zostali źle wybrani, spośród ludzi słabych, niezdecydowanych i obojętnych na dobro publiczne. Opieka nad pacjentami jest byle jaka. Oczywiście, wszyscy biedacy uważają się za straconych, jeśli tylko ktoś im wspomni o ich hospitalizacji. Tam, do lazaretów, zwożeni są chorzy na cholerę i inne choroby: zabierani są na oślep, niekiedy zdarzają się prostu pijani, motłoch. Pacjenci ze zwykłymi chorobami zarażają się cholerą i umierają na cholerę tak, jak ci, którzy z nią tu przybyli. Nasza policja, która zawsze wyróżniała się bezczelnością i wymuszeniami, teraz, w tych ciężkich czasach, zamiast pracowitości i aktywności jedynie nasila swoje wady. Nie ma nikogo, kto tchnąłby nadzieję w ludzi i wzbudził w nich zaufanie do rządu. $\mathrm{Z}$ tego powodu poczynają się już niepokoje w różnych częściach miasta ${ }^{115}$.

Pierwszy z „cholerycznych buntów”, nazywany wówczas „babim”116 lub „dżumowym” (ponieważ przywleczoną do miasta chorobę uważano na początku za dżumę), wybuchł w Sewastopolu 3 czerwca 1830 r. W mieście i w jego okolicy epidemii nie było - były to zamieszki związane tylko i wyłącznie z wprowadzoną kwarantanną i jej regulacjami. Skala tych protestów był znaczna: objęły całe miasto, które przez pięć dni pozostawało pod kontrolą zbuntowanych ${ }^{117}$. Ponieważ jednak opór ten nie miał tak naprawdę nic wspólnego z „cholerycznymi buntami”, zasygnalizowano tutaj jedynie jego wybuch.

Bunty choleryczne w latach 1830-1831 (wybuchały również później, ale te wykraczają poza ramy czasowe niniejszego badania) w rzeczywistości miały różną skalę, lokalizację i kontekst społeczny, chociaż jednoczył je fakt, że pretekstem do wybuchu niezadowolenia społecznego były epidemie cholery, restrykcje władz z nią związane i rozchodzące się na jej temat słuchy. Podczas wszystkich tych rebelii personel medyczny pozostawał jednym z głównych celów ataków czerni: medycy byli dla chłopów postaciami obcymi (i jako inteligenci - potencjalnie wrogimi) $)^{118}$.

\footnotetext{
114 Idem, Распространение слухов, 117.

115 Никитенко, Записки, 58.

116 Канищев, Мещеряков, Яковлев, Тамбовский, 142.

117 Дубасов, Тамбовская.

118 Канищев, Мещеряков, Яковлев, Тамбовский, 36-37.
} 
Pierwsze sygnały o wrzeniach dochodziły spod Tambowa już 5 listopada, a 13 listopada o godz. 18 w Nikolskoje doszło do zamieszek, bo „salowi i sanitariusze, opiekujący się chorymi na cholerę, w sumie 12 osób, uciekli ze szpitala i rozpuścili pogłoski, że pacjenci są truci, zabijani i gotowani w kotłach i dlatego umierają"119. Najpierw splądrowano Iszutińskij szpital miejski. Za winnego, oprócz lekarzy, tłum uznał lokalnego duchownego, którego chciano pobić: miał być sprawcą wszystkich nieszczęść, bo „doniósł o chorobie” władzom. Plebs skuł obu lekarzy szpitalnych i sekretarza gubernialnego i osadził ich w lazarecie, w izbie choleryków, a chorych rozpuszczono do domów ${ }^{120}$. Zamieszki rozprzestrzeniły się po guberni, a tymczasem 14 listopada w Tambowie pojawiła się cholera. W okresie od 17 do 21 listopada $1830 \mathrm{r}^{121}$ rozruchy trwały nie tylko w Tambowie, ale i w jego okolicach (różnych częściach guberni, we wsi Ozerki - na zachodzie, Perkino - na północy i Nikolskoje - na południu ${ }^{122}$. Powtórzyły się na tym samym terytorium 62 lata później z tych samych, „cholerycznych” powodów.

Bezpośrednim pretekstem do wybuchu buntu 17 listopada była śmierć w szpitalu cholerycznym pacjenta chorego na padaczkę. Pięciotysięczny tłum między innymi pochwycił i uwięził samego gubernatora, a konna żandarmeria zdołała odbić go dopiero następnego dnia ${ }^{123}$. W nocy w mieście zaczęły się pogromy, wyłapywano lekarzy i urzędników, jednym i drugim zarzucając "trucie” mieszkańców. Rano wojsko uspokoiło tłum, ale 18 listopada znowu rozpoczęły się rozruchy. Plebs wdarł się ponownie do szpitala i, widząc chorych ogrzewanych gorącymi kąpielami w metalowych kotłach, uznał, że „są gotowani”. Prowodyrzy uzbroili się w pałki i piki - zrobione z leżącego na podwórcu drewna opałowego ${ }^{124}$ - i atakowali nimi personel. Pracownicy medyczni, ratując się, zbiegli ze szpitala. Jednak siły porządkowe $\mathrm{w}$ końcu wyparły rebeliantów z miasta, a buntownicy rozsiali się po okolicznych wsiach i osiedlach ${ }^{125}$. Kolejnego dnia wojsko i żandarmeria już całkowicie opanowały miasto, ale rozruchy jeszcze przez dwa dni wybuchały we wsiach wokół Tambowa. Inicjatorami zamieszek w Tambowie i jego okolicach w przeważającej masie byli mieszczanie, chłopstwo i woźnice, w mniejszym stopniu - kupcy i ich służba ${ }^{126}$ (mieszczanie - 78\%, osadnicy wojskowi $7,5 \%$, woźnice $-7,5 \%$, kupcy - $2,5 \%$, urzędnicy - $2,5 \%$, oficerowie rezerwy $0,5 \%$ - liczby oparto na analizie pochodzenia społecznego skazanych za rozruchy w Tambowie) $)^{127}$. Ich podstawowym celem działania było zamknięcie i likwidacja

\footnotetext{
119 Ibidem, 151-152.

120 Ibidem.

121 Ibidem, 142.

122 Ibidem, 156.

123 Дубасов, Тамбовская.

124 Канищев, Мещеряков, Яковлев, Тамбовский, 187-188.

125 Ibidem, 174.

126 Ibidem, 210.

127 Tabela nr 12, za: Канищев, Мещеряков, Яковлев, Тамбовский, 237.
} 
„szpitali cholerycznych”, a także odwołanie zarządzeń o reżymie sanitarnym (tj. kwarantanny) ${ }^{128}$. Jak zwykle podczas wzburzenia społecznego, działania tłumu były i spontaniczne, i świadome (głównie podżegaczy). Wobec tych ostatnich nie od razu podjęto represje: najpierw policja zidentyfikowała prowokatorów. Było ich tylu, że cesarz zatwierdzał wyroki przez siedem miesięcy, od grudnia 1830 do lipca 1831 r. Tymczasem w 1831 r. cholera dwukrotnie powróciła do guberni tambowskiej. Dopiero 1 września 1831 r. w Tambowie doszło do wykonania wcześniej wydanych wyroków ${ }^{129}$ : dwie osoby skazano na śmierć przez powieszenie, cztery - na 50 uderzeń biczem, wypalenie piętna i katorgę, 14 - na praszczęty ${ }^{130}$ i zesłanie na Sybir, sześć - na wybatożenie i przymusową służbę wojskową, cztery - na 200 batów i zesłanie, jedną na 150 batów. Oprócz tego 16 osób skazano na dwa miesiące prac przymusowych $\mathrm{w}$ więzieniu, 53 - na jeden miesiąc tych prac. Jedną osobę skazano na trzy, drugą na dwa miesiące więzienia ${ }^{131}$.

„Zamieszki” w Tambowie poprzedziły rozruchy w wielu punktach Rosji, jednak kolejnych nie nagłaśniano. Już w październiku 1830 r. chłopi w niektórych obwodach w prowincji kazańskiej odmawiali podjęcia środków zapobiegawczych przeciwko cholerze, trochę później (przełom października i listopada) tak samo postąpili mieszkańcy kilku wsi obwodu kałuskiego, jeszcze później - w obwodzie moskiewskim. Potem niepokoje ogarnęły Bataszewy (obwód władimirski) oraz dwie wsie w obwodzie woroneskim. Jak donosił 7 grudnia carowi Mikołajowi I A.Ch. Benkendorf,

Żadne wyroki skazujące nie mogły ostudzić tych chłopów i powstrzymać buntu. 15 listopada zgromadziło się około 2000 osób i wybijając okna, włamali się siłą do mieszkania komendanta policji, pobili towarzyszących mu urzędników, zabrali im walizki, zwitki dokumentów i inne rzeczy, zniszczyli lekarstwa, które znajdowały się w powozie lekarza, [...]; pobili nawet popa, który chciał ich upomniećc ${ }^{132}$.

21 czerwca 1831 r. wśród mieszkańców stolicy kolportowano pogłoski o lekarzach, którzy zatruwają pospólstwo. Ponieważ instrukcja ministerialna zalecała w celu dezynfekcji noszenie ze sobą „butelki z roztworem sody chlorowanej lub octu, którą używa się do przecierania rąk i okolic nosa, oraz noszenia ze sobą woreczka sproszkowanego chlorku wapnia", posłuszni obywatele byli łatwym celem ataków - środki te nie chroniły przed chorobą, ale „podejrzliwy tłum, który łapał lekarzy, urzędników i osoby wyglądające na cudzoziemców, zmuszał tych gorliwych wykonawców poleceń władz do zjadania znalezionych przy nich

128 Канищев, Мещеряков, Яковлев, Тамбовский, 314.

129 Ibidem, 221.

130 Rodzaj kary cielesnej stosowanej w armii rosyjskiej (do końca XIX w. włącznie) polegającej na przepędzeniu (czasami wielokrotnym) skazanego pomiędzy dwoma szeregami żołnierzy wyposażonych w baty, kije, rózgi itp.

131 Ibidem, 222.

132 Канищев, Мещеряков, Яковлев, Тамбовский, 143-144. 
chemikaliów na dowód, że nie są trucizną, a ich posiadacze nie knują niczego zbrodniczego. [...] Pogłoski, że nie ma cholery, ale są otrucia, wywołały liczne zaburzenia $\mathrm{w}$ mieście" 133 . Z Petersburga $\mathrm{z}$ prędkością wiatru plotki przeniosły się na prowincję, gdzie wznieciły pożary: między innymi rebelię osadników wojskowych w guberni nowogrodzkiej. 22 czerwca w stolicy grupy pieszych napadały na przechodniów, którzy wydawali się im być lekarzami. Prowodyrzy przeszukiwali „wózki choleryczne” i dorożki wiozące medyków, wszystkich zatrzymywano, wszczynano też bójki z policjantami ${ }^{134}$. Były ofiary w ludziach ${ }^{135}$. Tłum zebrany na placu Siennym wyruszył na pogrom centralnego szpitala cholerycznego. Generał-gubernator Petersburga skierował w jego stronę dwa bataliony wojska i oddział żandarmów. Motłoch zatrzymał się przed kordonem, wtedy według rządowej prasy ${ }^{136}$ na plac przyjechał car i uśmierzył czerń ${ }^{137}$. Rozruchy w stolicy nie trwały długo - Petersburg był miastem zawsze pełnym wojska i autorytet cara też był tu wszechobecny: przecież mieszkańcami stolicy (oprócz wojskowych) byli przede wszystkim urzędnicy imperialni. Siły policyjne i wojskowe szybko rozproszyły niespokojny element, a ten - aby uniknąć konsekwencji - opuścił miasto i skierował na prowincję. Sama policja również wyekspediowała z Petersburga tych spośród zatrzymanych, którym nie udało się udowodnić konkretnych przestępstw.

\section{Osadnicy wojskowi w guberni Nowogrodzkiej}

Jeszcze za Aleksandra I osadzono w powiecie miasta Stara Rusa (i w samym mieście, które było 15 . wydzielonym okręgiem) oraz w powiecie nowogrodzkim osadników wojskowych. Razem rozdzielono ich na 15 okręgów. „Wybudowano dla nich 18350 domów (chat) i zamieszkiwało je 121676 dusz"138. W $1830 \mathrm{r}$. większość żołnierzy z tutejszych jednostek posłano do stłumienia powstania listopadowego. We wsiach pozostali przede wszystkim młodzi stażem rekruci, którzy niedawno trafili do armii. Właśnie wśród nich rozchodziły się plotki, że ludzie umierają „nie od cholery, tylko od trucizny, i to lokalni przełożeni są w spisku, który dąży do wytępienia biednego ludu przez wytrucie go"139. Plotki nasiliły się po likwidacji buntu w Petersburgu, kiedy dotarli na prowincję jego uczestnicy,

\footnotetext{
133 Токаревич, Грекова, По следам, 22.

134 Дубасов, Тамбовская.

135 Канищев, Мещеряков, Яковлев, Тамбовский, 261-262.

136 Zdaniem historyków buntowników uśmierzyło wojsko, a car pojawił się po buncie. Patrz szerzej: Канищев, Мещеряков, Яковлев, Тамбовский, 261-262.

137 Никитенко, Записки, 58.

138 Слезскинскій, Бунтъ военныхъ поселянъ въ холеру 1831 г. (Н. Новгородъ: Типолитографія Новгородской губернии правленія, 1894), 1.

139 Евстафьев, Восстание, 37.
} 
uciekający przed represjami. Do tego doszło około 12 tys. domniemanych uczestników tych zamieszek, których wysiedlono z Petersburga: „przechodząc przez ziemie nowogrodzkie przynieśli i kolportowali słuchy o tym, że cholery nie ma, są tylko otrucia i winni w tym są przełożeni [mieli zatruwać wodę i pożywienie - Z.L.]"140.

Nie był to, rzecz jasna, jedyny powód zamieszek, ale raczej ostatni bodziec do wybuchu rebelii, lud bardziej był niezadowolony z restrykcji antycholerycznych, które wprowadził minister Zakrijewskij, niż z cholery, której - póki co - nie doznał141.

Bunt trwał cały miesiąc (od 10/11 lipca do 10 sierpnia 1831 r.) $)^{142}$ i chociaż zaczął się w jednym miasteczku (Stara Rusa), to szybko rozprzestrzenił się na kilkanaście powiatów dwóch guberni. Niejednokrotnie po zdławieniu w jednym miejscu przycichał, a później wracał. Podczas zamieszek, które wybuchły 10 lipca 1831 r. (lub 11 - źródła podają różne daty) ${ }^{143}$ w Starej Rusie, sytuacja sprzyjała buntownikom - w mieście nie było wojska ${ }^{144}$, które walczyło w Polsce, i rabacja szybko rozszerzyła się na pobliskie osady wojskowe. Rozruchy były krwawe, bito i zabijano lekarzy, personel medyczny, żołnierzy, funkcjonariuszy, urzędników, a nawet popów. Dokonywano grabieży w części domów szlachty i urzędników w mieście ${ }^{145}$. W pierwszą noc rozgromiono aptekę na placu miejskim, a jej właściciela, aptekarza Wajgnera (Вайгнер) zabito ${ }^{146}$. Motłoch polował na oficerów przeszukiwał domy, aresztował ich oraz urzędników, policjantów, właścicieli ziemskich i duchowieństwo, potem pobitych zgromadzono na placu miejskim, gdzie miano ich „sądzić”. Rozpoczęły się nawet przygotowania do kaźni ${ }^{147}$, ale w nocy do miasta wkroczyło wojsko, więc egzekucje się nie odbyły. W buntach wzięli udział mieszczanie i osadnicy wojskowi - marynarze z floty wojennej, żołnierze z 3. i 4. pułku karabinierów, z pułków Jekaterinosławskiego, Wirtemberskiego, Meklemburskiego i Kijowskiego oraz z jednostek artylerii ${ }^{148}$.

Generał Aleksander Chrystoforowicz Eiler (Александр Христофорович Эйлер), dowodzący operacją tłumienia rozruchów, zameldował natychmiast carowi, że przyczyną buntu jest pojawienie się cholery i brak zaufania osadników do ich dowództwa, które jak podejrzewano, chce ich wytrućc ${ }^{149}$.

Aby przybliżyć przebieg wydarzeń, przytaczam wyimek z późniejszych akt sądowych „Sprawy o powieszenie za nogi przez osadników wojskowych

\footnotetext{
$140 \quad$ Ibidem, 39.

141 Ibidem, 38.

142 Ibidem, 73.

143 Ibidem, 39.

144 Ibidem.

145 Канищев, Мещеряков, Яковлев, Тамбовский, 262.

146 Bосстание военных, 40.

147 Ibidem, 41.

148 Слезскинскій, Бунтъ военныхъ, 1.

149 Bосстание военных, 44-45.
} 
duchownego Ioana Parowa” (Дъло о повъшеніи за ноги военными поселянами священника Іоана Парвова):

W czasie zamieszek, które miały miejsce w okręgu zamieszkałym przez wieśniaków osadników wojskowych z 3. pułku karabinierów przeciwko swoim przełożonym i ich zamordowanie w dniu 13 lipca br., z tego powodu, że bardzo często w celach służbowych miałem kontakty z tymi samymi przełożonymi, stałem się ofiarą zbuntowanych, w podobny sposób ujęty i potraktowany. O trzeciej po południu uczestnicy zamieszek schwytali mnie na brzegu rzeki Łowati, przy czym bezlitośnie pobili pałkami bez żadnego powodu. Zakrwawiony, nieprzytomny zostałem przez nich zaciągnięty do mojego domu. W nim nie było już ani jednego całego okna. Po wyłamaniu zamków w spiżarni i moich skrzyniach przeprowadzono przeszukiwanie w celu znalezienia jakiejś trucizny. Przez ten cały czas byłem pod silną strażą. Nic nie znaleziono. Potem buntownicy zaciągnęli mnie na cmentarz we wsi Kołomno, żeby odebrać mi życie. Przywiązali mnie za nogi do poprzeczek wzniesionych nad rowem przydrożnym, ponownie pobili mnie okrutnie pałkami i drzewcami proporców pułkowych. Następnie zawlekli mnie do wsi Ostratowo, a tam uratowali mnie niektórzy z moich parafian ze wsi Sługino i Ostratowo. 14-tego lipca otrzymałem wiadomość, że w nocy mój dom został splądrowany przez tych samych buntowników, którzy mnie pobili, zjedli nawet prowizje, które sobie przygotowałem ${ }^{150}$.

Buntownicy przemieszczali się od sioła do sioła, wszczynając zamieszki ciągle w nowych miejscach, i - zanim przybyły wojskowe posiłki, aby uśmierzyć rozruchy ruszali dalej. Ponieważ we wsiach lekarzy prawie nie było, ich głównym wrogiem stali się przełożeni i urzędnicy: „14 lipca wiejski pisarz wdrapał się na dzwonnicę i podniósł larum, tłumy mieszkańców okolicznych siół zapełniły wieś, wyciągnęli oni z kwatery dowódcę tutejszego batalionu osadników, oficerów i lekarza, pobili ich na placu wiejskim i zamknęli na wartowni, stawiając tam własną wartę" - tak wspominał bunt jeden z świadków wydarzeńn ${ }^{151}$. Ogółem ofiarami buntowników stało się 207 osób: jeden chłop pańszczyźniany, dziewięciu szeregowców, jeden cyrulik, jeden pisarz, czterech nauczycieli, ośmiu leśniczych, 26 młodszych podoficerów, jeden starszy podoficer, 10 zbrojmistrzów, 10 feldfebli, jeden pomocnik leśniczego, jeden nadleśniczy, dwóch pomocników weterynarzy, jeden weterynarz, czterech nadzorców dzielnicowych, jeden oficer policji, jeden naczelnik gubernialnej policji, jeden naczelnik staroruskiego komitetu ekonomicznego, jeden urzędnik chołmskiego sądu ziemskiego, jeden członek staroruskiego komitetu ekonomicznego, pięciu właścicieli ziemskich, czterech duchownych, siedmiu intendentów, czterech lekarzy, pięciu lekarzy sztabowych, dwóch chorążych, dwóch podporuczników, 15 poruczników,

150 „Списокъ съ прошенія старорусскаго военнаго поселенія, округа 3-го карабинернаго полка, присутствующаго въ полковомъ комитетъ священника села Коломны Іоанна Парвова 9 августа 1831 г., w Іоаннъ Парвовъ, Петр Николаевич Диринъ, Бунтъ военныхъ поселянъ въ 1831 2., za: Русская Старина, t. I (Санкт-Петербургъ: Типографія И.Н. Скороходова, 1870), 275.

151 Иоанн (Ян) К. Каневскій, „Эпизодъ изъ бунта военныхъ поселянъ въ 1831 г.”, Историческій вюстникъ. Историко-литературный журналь XXVII (мартъ 1887): 683-684. 
17 kapitanów sztabowych, 20 kapitanów, 15 majorów, pięciu podpułkowników, jeden pułkownik, trzech generałów majorów (generałów brygady). Oprócz nich ucierpiało dziewięć kobiet ${ }^{152}$.

Działania władz nie były wystarczająco energiczne, bunt trwał długo i w dodatku żołnierze wysłani do jego stłumienia przechodzili na drugą stronę (m.in. 1 sierpnia tak uczyniła jedna z jednostek wojskowych w Starej Rusie, w rezultacie w mieście zamordowano dwóch generałów). Dopiero wejście 7 sierpnia do miasta i obu guberni oddziałów regularnej armii pozwoliło zakończyć rozruchy następnego dnia, gdy oddziały otwarły ogień do zebranego tłumu. Prawie natychmiast rozpoczęto rozprawy $\mathrm{z}$ buntownikami: 9 sierpnia powołano komisję śledczą, która 16 sierpnia przystąpiła do pracy ${ }^{153} .15$ stycznia następnego roku zapadły wyroki: za winnych buntu uznano 3960 (z ogólnej liczby 4518 aresztowanych $)^{154}$. Oprócz wymienionych już miejscowości choleryczne bunty miały miejsce w Twerskiej, Ołońcu, Mińsku, w guberniach kurskiej, władymirskiej, borgskiej i moskiewskiej, w miastach Rżew, Ostaszków, Staricy, Wyżnyj Wołczok, Archangielsk, wiosce Burnak w powiecie borysoglebskim i innych mniejszych miejscowościach ${ }^{155}$. Rozruchy spowodowane cholerą nie były zjawiskiem społecznym, do którego doszło tylko w carskiej Rosji, dochodziło do nich także w Austrii czy we Francji. A „w Poznaniu i Królewcu wojsko musiało interweniować, aby uspokoić protestującą część społeczeństwa”"156.

Lęk, bezsilność i uciążliwości życia w kwarantannie i samoizolacji były powodem depresji (zob. szerzej m.in. wiersze Aleksandra Puszkina z 1830 r. czy utwory innych literatów, np. nowela Aleksandra Orłowa; il. 7), załamań, plotek, ucieczek zamożnych mieszczan z miast na wieś, paniki w różnych jej przejawach, ale także bohaterstwa, nie tylko lekarzy. Jednak najważniejszym destrukcyjnym czynnikiem dla społeczeństwa, nie tylko w ówczesnej Rosji, był brak zaufania ludności do władz oraz konflikt pomiędzy poddanymi a rządzącymi. Ten właśnie brak zaufania sprzyjał szybkiemu rozprzestrzenianiu się pogłosek, bezkrytycznej wiarze w nie, a bunty choleryczne - najbardziej drastyczna forma wyrażenia protestów - udowodniły, że teorie spiskowe, wiara w złe zamiary Innego (Polaków, obcokrajowców, lekarzy, dowódców itp.) są powszechne. Dla caratu bunty nowogrodzkie były potrójną klęską. Po pierwsze, udowodniły fiasko socjotechnicznych planów poprzednika Mikołaja I, który uważał, że wioski osadników wojskowych z założenia będą ostoją ideologii caratu, siedzibami wiernopoddańczych oddziałów, które można będzie ad hoc mobilizować. Tymczasem stały się kolebką wielu długotrwałych buntów przeciw dowództwu i rozporządzeniom władz. Po drugie, wojska regularne przechodziły na stronę

\footnotetext{
152 Слезскинскій, Бунтъ военныхъ, 193-194.

153 Восстание военных, 73.

154 Ibidem, 74.

155 Канищев, Мещеряков, Яковлев, Тамбовский, 263-264.

156 Zajączkowski, Epidemia cholery, 27.
} 


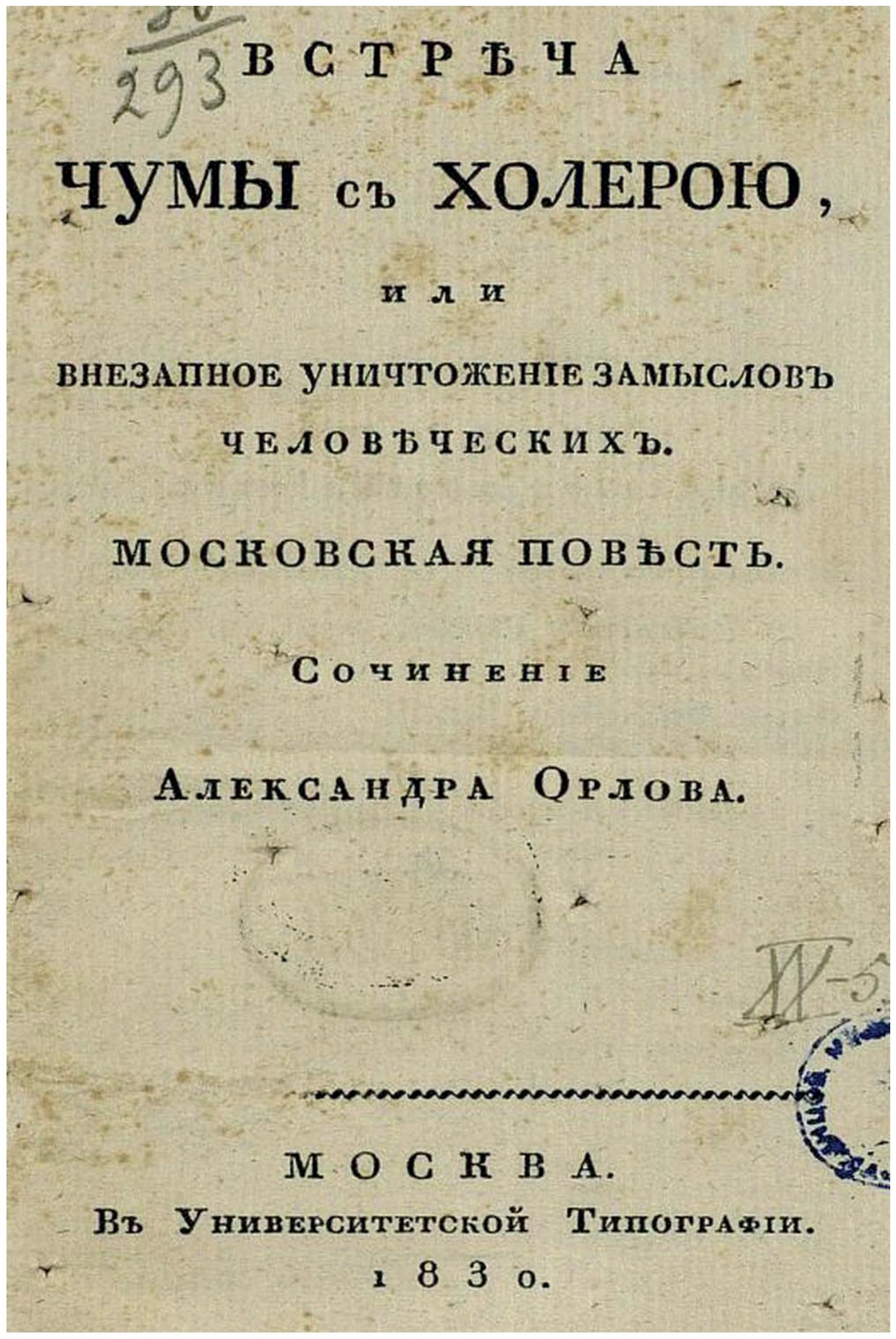

Il. 7. Okładka noweli Орлов Александр, Встреча чумы с холерою, или Внезапное уничтожение замыслов человеческих... (Moskwa 1830) Fot. Zbigniew Landowski 
buntowników, co źle świadczyło o morale armii, a po trzecie, osadnicy wojskowi byli zdemobilizowanymi żołnierzami, czyli chłopami już przeszkolonymi, a jednak nadal wśród nich było wielu analfabetów. Choć nie byli oni już ciemnymi chłopami pańszczyźnianymi, to jednak bezkrytycznie wierzyli w zabobony, w nieistnienie zarazy i w złą wolę własnych dowódców. Wyszło na jaw, że upadło nie tylko morale armii, lecz regres dotyczył całego podstawowego programu szkolenia żołnierzy, a ci pozostali nieukami. Także stan służby zdrowia w kraju i w wojsku okazał się poniżej krytyki: od 1823 r. po 1919 r. w Rosji zmarło w rezultacie cholery 2,5 mln ludzi, a chorowało na nią ponad $5 \mathrm{mln}$. Tylko w latach trzydziestych XIX w. zmarło około 200 tys. ludzi ${ }^{157}$. Na początku najbardziej ucierpiały południowo-zachodnie regiony Rosji: w 1830 r. epidemia objęła ponad 30 guberni, łącznie zmarło około 37,5 tys. osób (68 tys. osób zachorowało); rok później cholera opanowała już 48 guberni, a liczba zgonów sięgnęła 200 tys. ${ }^{158}$ Jednak nie tylko cholera dziesiątkowała mieszkańców Rosji: jedną z ważnych przyczyn wysokiej śmiertelności w carskim imperium były ostre choroby zakaźne: epidemie tyfusu, cholery, ospy, czerwonki, malarii, a wcześniej - dżumy ${ }^{159}$.

Niniejsza praca ma interdyscyplinarny charakter i dotyczy zarówno historii, jak i antropologii medycznej ${ }^{160}$, badanie potwierdziło, że sposób postrzegania konfliktów społecznych z perspektywy pierwszych rosyjskich badaczy i późniejszych, z okresu socjalizmu, był politycznie determinowany - jako przyczynę wybuchu niezadowolenia społecznego ukazywano wyłącznie ten powód, który był na rękę aktualnej władzy, czyli w okresie caratu - cholerę, w okresie socjalizmu - walkę klas ${ }^{161}$.

Właściwym powodem wybuchu niepokojów był konglomerat wielu czynników, a reakcje społeczeństwa były wynikiem licznych składowych - lęku przed chorobą, oddźwięku na restrykcje władz, depresji, reakcji na kryzys gospodarczy, głodu, wojen, ciemnoty mas społecznych (łącznie z analfabetyzmem chłopów) ${ }^{162}$, niewiedzy medycznej, konfliktów klasowych (m.in. brak zaufania do władz, a nawet podejrzewanie ich o spisek) itd. Stąd trudno o jednoznaczną odpowiedź, czy cholera była najważniejszą przyczyną buntów i pozostałych form reakcji mas społecznych na pandemię. Zamieszki były ostateczną formą protestów - pierwsze

157 Владимир Н. Золотницкий, Азиатская холера. Причина её, пути распространения и меры борьбы с нею, изд. 2-е доп. (Нижний Новгород 1919), 5.

158 Трушин, Борьба с холерой, 38.

159 Вячеслав Н. Авлиев, „Общие меры борьбы с холерой в российской провинции в начале XIX в. (На материалах Астрахани и калмыцкой степи астраханской губернии)”, Современные проблемы науки и образования 2-3 (2015): 182.

160 Zob. szerzej m.in. Дмитрий В. Михель, Медицинская антропология: исследуя опьт болезни и системы врачевания (Саратов: Саратовский Государственный Технический Университет имени Гагарина Ю.А., 2015).

161 Канищев, Мещеряков, Яковлев, Тамбовский, 10.

162 Ibidem, 36-37. 
reakcje ograniczały się do ucieczki z miast, a dla tych, którzy nie mogli ich opuścić do wycofania się w sacrum, kontekst religijny (msze, procesje, modły, traktowane jako panaceum na „dopust Boży”), dopiero później przerodziły się w bardziej agresywne formy sprzeciwu przeciw nauce (lekarze) i władzy (dowództwo). Wszystkie bunty choleryczne zostały zdławione siłą: zastraszeniem użycia broni lub wręcz przelewem krwi, mimo że w trakcie ich gaszenia za każdym razem usiłowano uczynić to drogą pokojową, przy czym nie była to zasługa władz państwa, tylko indywidualna dowódców wojskowych. Kryzys nie został przezwyciężony dzięki administracji państwowej, władzy czy carowi, jak głosiła prasa. Restrykcje administracyjno-medyczne zdjęto, ponieważ cholera odeszła, a buntownicy ponieśli surowe kary. Życie (gospodarcze i społeczne) wróciło w swoje koleiny, do stanu sprzed epidemii. Jaki był stan świadomości szerokich mas po rozruchach i po epidemii - nie wiadomo, bo nie prowadzono badań, ale propaganda państwowa na lata narzuciła ,jedynie właściwy” kierunek interpretacji powodów zaburzeń społecznych: choleryczny charakter buntów. Ich skala była na tyle duża, że zjawisk tych nie dało się ukryć. Zaangażowane w nie były (aktywnie i biernie) co najmniej setki tysięcy mieszkańców Rosji - ale skanalizowano ich powód: winna była cholera. Jednocześnie niejasny jest stosunek rosyjskiego społeczeństwa do samej choroby - w XIX w. cholera pojawiała się jako epidemia kilkukrotnie, łączna liczba ofiar w ciągu prawie stulecia przekraczała $2 \mathrm{mln}$, ale w tym samym okresie w Rosji tylko na gruźlicę zmarło ponad 2,5 mln osób, więc ustawiczne obcowanie ze śmiertelnymi chorobami mogło doprowadzić do pewnej znieczulicy społecznej. Chociaż... przeczą temu kolejne zamieszki i bunty „choleryczne”, do których dochodziło przy okazji następnych pandemii, na przykład w latach dziewięćdziesiątych XIX w.

\section{Zbigniew Landowski}

\section{Social reactions to the first cholera pandemic in Tsarist Russia on the basis of a review of the contemporary press and documents (XIX ${ }^{\text {th }}$ century)}

This article presents the social context of the cholera epidemic in 1830 in Tsarist Russia, focusing on the reaction of the authorities, including imposed restrictions, as well as social reactions to the disease itself, along with official restrictions, embracing extreme forms of social protests, the so-called "Cholera Riots". There are also descriptions of medical recommendations, prophylaxis, and the then recommended methods of treating cholera, the position and activities of the church and the role of the media via the example of the daily newspaper Съверная пчела. 